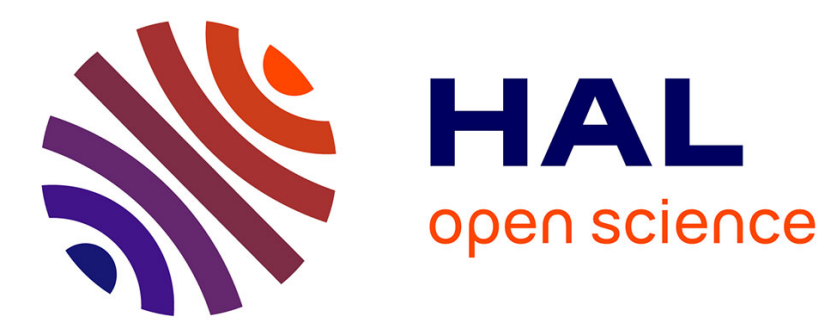

\title{
Heterogeneous distribution of rainfall and discharge regimes in the Ecuadorian Amazon basin
}

Alain Laraque, Josyane Ronchail, Gérard Cochonneau, Rodrigo Pombosa, Jean Loup Guyot

\section{To cite this version:}

Alain Laraque, Josyane Ronchail, Gérard Cochonneau, Rodrigo Pombosa, Jean Loup Guyot. Heterogeneous distribution of rainfall and discharge regimes in the Ecuadorian Amazon basin. Journal of Hydrometeorology, 2007, 8 (6), pp.1364-1381. 10.1175/2007JHM784.1 . ird-00555542

\section{HAL Id: ird-00555542 \\ https://hal.ird.fr/ird-00555542}

Submitted on 13 Jan 2011

HAL is a multi-disciplinary open access archive for the deposit and dissemination of scientific research documents, whether they are published or not. The documents may come from teaching and research institutions in France or abroad, or from public or private research centers.
L'archive ouverte pluridisciplinaire HAL, est destinée au dépôt et à la diffusion de documents scientifiques de niveau recherche, publiés ou non, émanant des établissements d'enseignement et de recherche français ou étrangers, des laboratoires publics ou privés. 


\title{
Heterogeneous Distribution of Rainfall and Discharge Regimes in the Ecuadorian Amazon Basin
}

\author{
A. LARAQUE \\ Institute for Research and Development, OBHI, Fort de France, France \\ J. RONCHAIL \\ Paris 7 University-LOCEAN/IPSL, Paris, France \\ G. COCHONNEAU \\ IRD-LMTG, Montpellier, France \\ R. Pombosa \\ INAMHI, Quito, Ecuador \\ J. L. GUYOT \\ IRD-LMTG, Lima, Perú
}

(Manuscript received 10 May 2006, in final form 2 April 2007)

\begin{abstract}
The hydrology of the Ecuadorian Amazon basin is still poorly documented. The research developed between the Institute for Research and Development (IRD) and the National Institute of Meteorology and Hydrology (INAMHI) of Ecuador takes advantage of a newly available rainfall and discharge dataset to explore spatial distribution and regimes in this region $\left(135600 \mathrm{~km}^{2}\right)$. Forty-seven rainfall and 27 discharge stations were retained over a 30-yr period (1965-94). A new annual isoyets map is proposed for the Amazon basin of Ecuador. The most striking result is a high spatial regime variability, to the extent that out-of-phase regimes are found in nearby stations. Indeed, in high intra-Andean basins there is a marked bimodal rainfall regime, with maxima in March-April and in October and a minimum from June to August. On the contrary, as moisture transport reaches a maximum in June, a rainfall peak can also be observed at the same time on slopes to the east due to the moist easterlies. In the lowlands, a bimodal regime is observed as in the intra-Andean basin; as water vapor is abundant, seasonal variability is not as strong as in the Andes. Discharge regimes are related to rainfall regimes. However, even if no delay is observed between maximum rainfall and maximum discharge in the inner Andean basins, a delay varying from one to two months is observed in larger basins. Soil conditions also affect the discharge regime in the upper and inner Andes: paramo soils (a kind of tundra formation) release water, in particular after the March-April rainfall peak, and sustain the dry season runoff.
\end{abstract}

\section{Introduction}

Andean regions are characterized by tectonic activity with intensive volcanic and seismic episodes, and the foreland basins undergo strong erosion processes that are related to the Andes uplifts (Laraque et al.

Corresponding author address: A. Laraque, Institute for Research and Development, OBHI, BP 8006, 97259 Fort de France, France.

E-mail: alain.laraque@ird-mq.fr 2004a,b). As rainfall and streamflow mobilize these sediments, attention has been paid more particularly to the hydrology of the Andean countries of the Amazon basin within the framework of the Hydrogeodynamics of the Amazon Basin (HYBAM) project (www.mpl. ird.fr/hybam), an international cooperation program between the Institute for Research and Development (IRD) and Amazonian country institutions.

The research program developed between IRD and the National Institute of Meteorology and Hydrology (INAMHI) of Ecuador gave us the opportunity to work 
on rainfall and discharge records, to control these data, and to complete the existing network. A first glance at the mean monthly data showed that the annual cycle of rainfall and streamflow has a high spatial variability in the Amazonian basins of Ecuador. Nonetheless, the knowledge of rainfall and discharge regimes is of great importance for the seasonal prediction of natural phenomena. For example, in a tropical region the high water season naturally follows the low water season; but what can be expected of a basin formed by two tributaries, each with a different regime? This feature, frequently found in large basins, is not so common in small basins. Additionally, the mean features of rainfall and discharge regimes in Ecuador, and especially in the Amazon basin of Ecuador, are rather poorly documented.

In eastern Ecuador, low-level air convergence and abundant precipitations are promoted by the instability of the moist air coming from the Atlantic or recycled over the forests and swamplands (Johnson 1976; Hastenrath 1981) and by the concave shape of the eastern slopes of the Andes (Nobre 1983). The Andean Cordillera uplifts the moist Amazonian air, and rainfall is enhanced on the slopes to the east. However, slopes on the leeward side remain drier and finally the complexities of the terrain induce a strong spatial rainfall variability (Johnson 1976; Figueroa and Nobre 1990). There is no simple relationship between altitude and rainfall, although, precipitations are heavy on the lower slopes, and tend to diminish over 2500 masl (Johnson 1976; Pourrut 1994). Figueroa and Nobre (1990) explain the main features of rainfall regimes in the Amazon basin. The absence of a dry season in the western Amazon is attributed to the presence of the Andes to the west, probably providing sustained convergence of the low-level flow throughout the year. Johnson (1976) points out a change in the seasonal rainfall distribution of the eastern plains that occurs at the Andean foothills. Thus, the midyear heavy rain period in the plain changes to the midyear dry period in the highlands. This is consistent with the bimodal rainfall regime in the inter-Andean valleys, between the western and the eastern Cordillera, and over the high eastern slopes of the Andes, described by Bendix and Lauer (1992), Pourrut (1994), Rossel (1997), Vuille et al. (2000a), and Francou et al. (2004). They report two rainy seasons (February-May and October-November) in the highlands and a first dry season (June-September), which is much more pronounced than the second one around December. A similar cycle with two maxima in AprilMay and October-November and two minima in December-January and July-August can also be observed in the Andes in Venezuela and Colombia (Pulwarty et al. 1992; Poveda 2004). The semiannual cycle of rainfall in the Andes results from the latitudinal oscillation of convection maximum that depends on the annual cycle of temperature and insolation (Kousky et al. 1988; Horel et al. 1989; Figueroa and Nobre 1990). The semiannual cycle is also determined by vapor transport from the Atlantic, by surface easterlies and medium- and upper-level circulation (Cuartas and Poveda 2002). Bendix and Lauer (1992) also mentioned a special regime on the eastern slopes of the Andes, between approximately 1000 and 3200 masl, which is characterized by a rainy season occurring in July and no real dry season.

With respect to streamflows, Pourrut (1994) reports two different regimes in the Andes, one with two maxima, like rainfall, in March-April and in OctoberNovember, and another associated with ice melting in the rivers flowing from glaciers in the Andean Cordillera. In this case, the maximum occurs during the dry season in June-July. However studies conducted by Favier et al. (2004) and B. Cáceres (2005, personal communication) show that ice melting is insignificant because the four glaciers providing water to the Amazon basin cover very small surfaces $\left(5\right.$ to $7 \mathrm{~km}^{2}$ ) at the top of the Cotopaxi, Antisana, Cayambe, and Altar volcanoes. In the Amazonian plain, Pourrut (1994) describes a maximum runoff in June-July and a minimum in December-January.

Many investigations about rainfall in Ecuador mainly focus on the Pacific coast, where El Niño events cause dramatic rainfall. Although it covers half the surface of the country, the Amazonian region of Ecuador is poorly documented because of its remoteness and sparse population. Nevertheless with oil found in the region 30 years ago, economic interest has sprung up. It is much worse when considering discharge in the Amazon tributaries, although there exists a major need for discharge forecast as demonstrated by the dramatic 2005 low water episode in the Amazon basin (Williams et al. 2005). This is why this paper aims to take advantage of the availability of extensive rainfall and the discharge dataset to give more information about rainfall and the discharge regime in the Amazonian basins of Ecuador. The paper is organized as follows. The geography of the eastern basins of the Ecuadorian Andes is described in section 2. An overview of the data and methods used in this work is given in section 3. Spatial distribution of mean values and regimes is presented and discussed in section 4. Finally, conclusions are given in section 5 .

\section{Study area}

Ecuador is situated in western South America on either side of the equator-which in Spanish gives its 


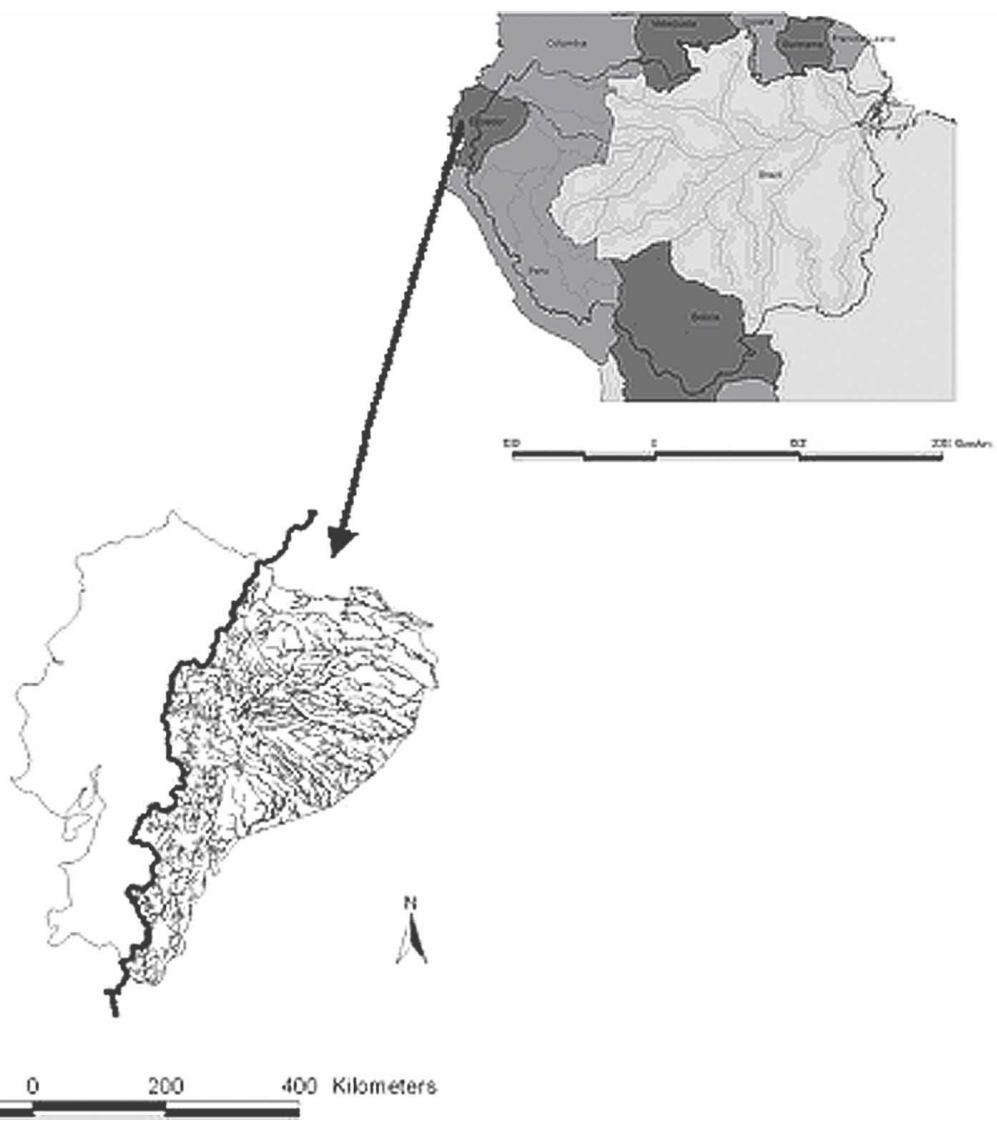

FIG. 1. Ecuadorian Amazon hydrographical network. The bold line is the limit of the Amazon basin.

name to the country-between Colombia to the north, Peru to the east and south, and the Pacific Ocean to the west. With a north-south orientation, the Andes form the runoff dividing line between the Pacific Ocean and the Amazon basins. The Ecuadorian Amazon basin covers $135600 \mathrm{~km}^{2}$. This corresponds to the eastern half of Ecuador (Fig. 1). This region, located between latitudes $0^{\circ} 20^{\prime} \mathrm{N}$ and $4^{\circ} 30^{\prime} \mathrm{S}$, and longitudes $78^{\circ}$ and $75^{\circ} \mathrm{W}$, accounts for less than $3 \%$ of the total surface area of the Amazon basin $\left(6.1 \times 10^{6} \mathrm{~km}^{2}\right)$. It is divided into two parts: the foreland, which forms the edge of the humid, equatorial plain of the Amazon to the east and the Andean Mountain range to the west. The Cordillera-between 4000 and 6300 masl, the highest peaks covered by glaciers-is scattered with several volcanoes, some of which are still active today. The eastern side of the "Eastern Cordillera Real" has steep slopes down to 500 masl over $100 \mathrm{~km}$ only. Vegetation changes very quickly with altitude, from the highlands or "paramo" covered by "puna" (Andean name for a kind of tundra formation) at 3000 masl, to dense equatorial forests that cover the very humid low regions. In
1976 , this dense vegetation covered $82 \%$ of the eastern Ecuadorian basin (UNESCO 1980).

The eastern river network drains water toward the east, perpendicularly to the Cordillera, toward the Solimões/Amazonas River. From north to south, the main rivers leaving Ecuador are San Miguel-Putumayo, Aguarico, Napo, Curaray, Pintoyacu/Tigre, Corrientes, Pastaza, Morona, Santiago, and Chinchipe (Table 1 and Fig. 2). The three major eastern hydrographic basins of Ecuador are, in descending order: the Napo, Santiago, and Pastaza, covering approximately 31 400, 26300 , and $21100 \mathrm{~km}^{2}$, respectively, near the Peruvian border. The San Miguel River forms the border with Colombia in the northeast and belongs to the Putumayo River basin. This river flows from Colombia down to the border and becomes the Iça River in Brazil before flowing out into the Solimões/Amazonas River. The Aguarico River downstream forms the border with Peru in the extreme northeast of Ecuador, before ending on the left riverbank of the Napo River. Finally, in Peru, the Curaray River joins the Napo on its right bank, and the Corrientes River flows out into the Tigre River, also on 
TABLE 1. Main characteristics of the Ecuadorian Amazon basins: surface $\left(\mathrm{km}^{2}\right)$, Andean surface above $\left.500 \mathrm{masl}^{(\mathrm{km}}{ }^{2}\right)$, percentage of the surface in the Andes. See the location of the basins in Fig. 2. AJ denotes before junction and DJ denotes for after junction.

\begin{tabular}{|c|c|c|c|c|}
\hline $\begin{array}{l}\text { Code in } \\
\text { Fig. } 2\end{array}$ & $\begin{array}{c}\text { Basins } \\
\text { (from north to south) }\end{array}$ & $\begin{array}{l}\text { Total area } \\
\left(\mathrm{km}^{2}\right)\end{array}$ & $\begin{array}{c}\text { Andes area } \\
\left(>500 \text { masl }-\mathrm{km}^{2}\right)\end{array}$ & $\%$ Andes \\
\hline $\mathrm{a}$ and $\mathrm{a}^{\prime}$ & Putumayo and San Miguel & 7130 & 1400 & 19.6 \\
\hline $\mathrm{b}$ & Aguarico-AJ Napo & 13890 & 4480 & 32.3 \\
\hline $\mathrm{c}$ & Napo-AJ Aguarico & 31,410 & 14020 & 44.6 \\
\hline d & Curaray-Frontera & 16700 & 510 & 3.1 \\
\hline e & Pintoyacu/Tigre & 7100 & 2 & 0.0 \\
\hline $\mathrm{f}$ & Corrientes & 2020 & 90 & 4.5 \\
\hline $\mathrm{g}$ & Pastaza-Frontera & 21140 & 14630 & 69.2 \\
\hline $\mathrm{h}$ & Morona-Frontera & 6720 & 2720 & 40.5 \\
\hline $\mathrm{i}$ & Santiago-Frontera & 26340 & 26090 & 99.1 \\
\hline \multirow[t]{2}{*}{$\mathrm{j}$} & Chinchipe-Frontera & 3140 & 3140 & 100.0 \\
\hline & Total & 135590 & 67082 & 49.5 \\
\hline
\end{tabular}

its right bank. The other rivers flow directly into the left bank of the main Marañón/Amazonas axis. Half the eastern area belongs to the "Andean" region at an altitude of more than 500 masl. The 500-masl isolign skirts the northwest-southeast Pastaza alluvial fan that has a low altitude, between 500 and 800 masl (Bès de
Berc et al. 2005). The other half of the eastern area is part of the Amazonian Plains. It features a lack of relief and a dense network of rivers crossing the rain forest. Three river basins (Curaray, Tigre, and Corrientes) only flow in the Amazonian plain, while two others (Santiago and Chinchipe) are completely mountainous.

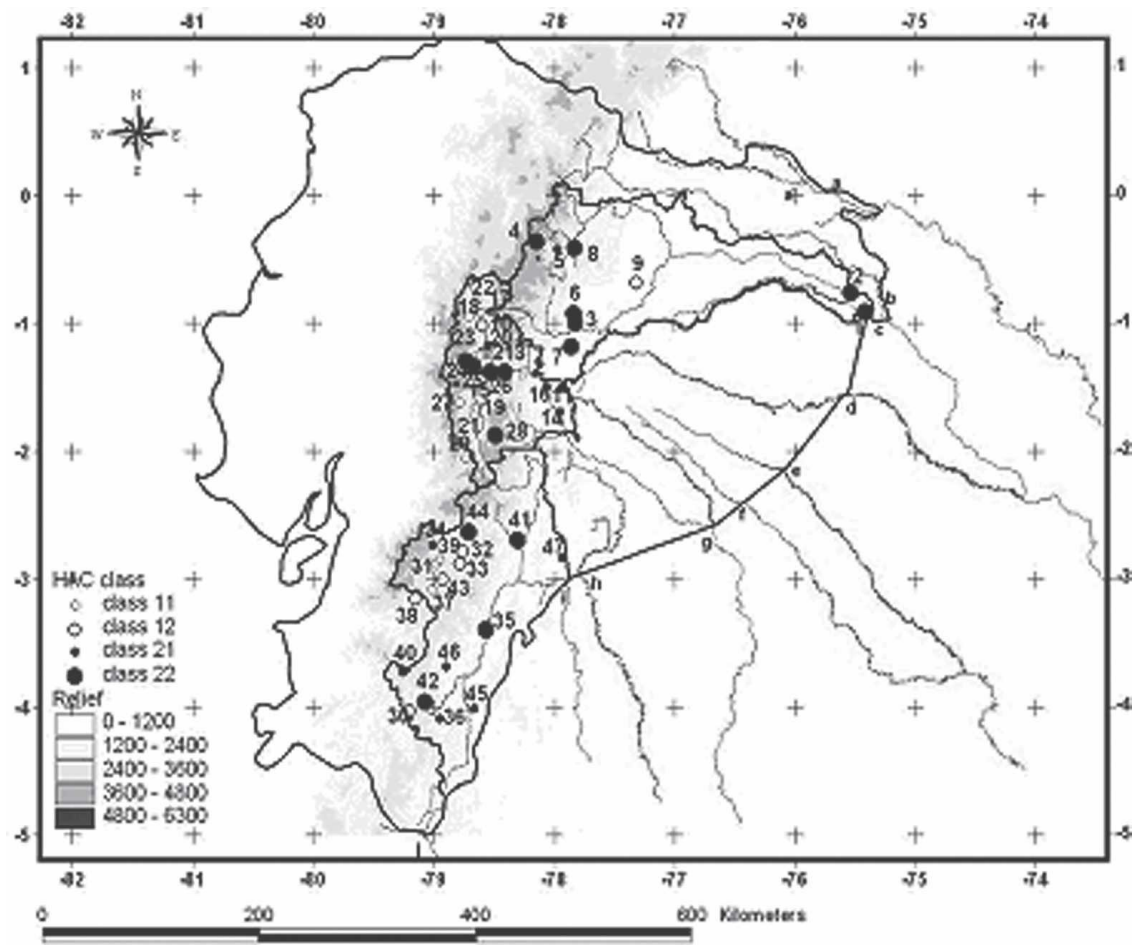

FIG. 2. Relief, location of the rain gauge stations, and geographic distribution of pluviometric regimes resulting from an HAC. Regime 1 is bimodal with a marked seasonality; the first maximum is in April in class 1-1 and in March in class 1-2. Regime 2 has a lower seasonality; in class 2-1 there are two relative maxima in April and October; in class 2-2 a relative maximum can be observed in June. River codes (letters) are listed in Table 1 and station codes (numbers) are listed in Table 2. From north to south bold lines underline the limits of the Napo, Pastaza, and Santiago basins. Altitude is in masl. 
All other rivers cross mountainous terrain, which accounts for $20 \%$ to $70 \%$ of their total area (Table 1 ).

\section{Data and methodology}

Hydro-pluviometric data are collected, processed, and corrected by INAMHI, which manages the national network. The hydrological stations of INAMHI are calibrated with the use of a current meter and are monitored by "observers" checking the water level twice a day. Two important hydrological stations, Francisco de Orellana monitored by the Observatory for Environmental Research (ORE)/HYBAM (www. ore-hybam.org) and Nuevo Rocafuerte on the Napo River, were recently calibrated (2001) by the HYBAM project (Laraque et al. 2004a,b) using an Acoustic Doppler Current Profiler (ADCP) based on the Doppler Effect (RDI 1996).

In the Amazon region, 159 rain gauges and 61 hydrological stations operate, with only a few stations in the plain, as a result their remoteness. Rainfall data are recorded at a monthly time scale and discharge data at a daily time scale. Gaps in rainfall data were not filled and monthly means have been computed with existing data. Limnigrams have been meticulously checked to detect anomalies and the good agreement between upstream and downstream station values has been controlled. Gaps in discharge data of less than 5 days have been filled as a function of the preceding and following values. Whenever possible, the gaps were filled using correlation with upstream data. Many rainfall and discharge records were not used, as series were either incomplete or too short. Hydrological and pluviometric stations with more than $60 \%$ missing data and records of less than 10 complete years were discarded.

In the end, 47 rainfall and 27 discharge stations were retained over a 30-yr period, from 1965 to 1994, with a good density of continuous data (Tables 2 and 3 ). Thirty out of 47 rainfall stations and 13 out of 27 discharge stations feature more that 20 complete years of data. However, two rainfall gauges and two hydrometric stations have also been retained to use data from remote regions with scarce information. Rainfall stations are the Yaupi station (number 47) with only five full data years and $84 \%$ missing data during the $1965-$ 94 period (Fig. 2 and Table 2), and the Yacuambi en La Paz station (number 46) with nine full data years and $73 \%$ missing data during the $1965-94$ period. Interestingly, they provide information about the easternmost regions of the Santiago basin (station 47) and about the Zamora valley, one of the two tributaries of the Santiago River (station 46). Hydrometric stations are Nuevo Rocafuerte (number 8 in Fig. 10), with seven full years and 71\% monthly missing data during the 196594 period, which controls the Ecuadorian Napo basin, and Francisco de Orellana (number 3 in Fig. 10), with eight full years and $68 \%$ monthly missing data during the 1965-94 period, located at the confluence of the main Napo tributaries at the outlet of the Andes. All stations are located in the Napo, the Pastaza, and the Santiago basins, and in the other basins of eastern Ecuador, discharge data are missing and rainfall data are very scarce.

Two new hydrometric stations, Puente La Union (Pastaza River) and Puerto Santiago (Santiago River) were set up in 2001 within the HYBAM project. Along with the Nuevo Rocafuerte station, they enable the large eastern hydrographic basins of Ecuador to be monitored: the whole Napo and Santiago basins and more than $60 \%$ of the Pastaza basin (Table 3 and Fig. 10). So far, limited data have been obtained for these two stations (three years of data since 2001). As the rating curves are still incomplete, their characteristics listed in Table 3 are given for information only.

The stationarity of records and the impact of El Niño events on rainfall and discharge have been examined to assess whether the mean monthly values used to analyze the regimes have been affected by the choice of the 1965-94 period. As a matter of fact, $75 \%$ of all rainfall stations exhibit records complete enough to look for a trend over this period. Twenty-six are stationary, 4 display a minor positive trend, and 2 display a negative one. Among the fluviometric stations, 12 are stationary, 4 have a decreasing discharge, and 9 are not complete enough to determine their trend. These results derived from correlation between rainfall or discharge values and time are significant at the $95 \%$ level.

On the other hand, the impact of El Niño-Southern Oscillation (ENSO) - which is a major source of interannual variability in certain regions of South America-has been studied mostly in the coastal and Andean regions of Ecuador (Rossel 1997; Vuille et al. 2000b; Bendix et al. 2004; Bendix et al. 2006, Cedeño et al. 2006). For the Amazon basin, Ronchail et al. (2002) found a low rainfall increase during El Niño in MarchMay, in 12 upper stations of the Santiago and Pastaza basins during the 1977-99 period. As El Niño events have been more frequent since 1976 (Trenberth and Hurrell 1994), regimes may have been modified since then. However, the rainfall regimes during El Niño years and during the mean 1965-94 years do not exhibit any changes except for the strength of the first rainy season. Therefore, it can be concluded that neither a trend nor different frequencies of ENSO events have affected the definition of rainfall regimes during the 1965-94 period. 
TABLE 2. Characteristics of the rain gauge stations (1965-94 period): basin, altitude (masl), number of complete years data, monthly missing data, mean annual rainfall $(\mathrm{mm})$, regime, and PR (ratio between maximum and minimum monthly rainfall). See the location of the rain gauge stations in Fig. 2.

\begin{tabular}{|c|c|c|c|c|c|c|c|c|}
\hline $\begin{array}{c}\text { Code } \\
\text { cf. Fig. } 2\end{array}$ & Pluviometric station & Basin & $\begin{array}{l}\text { Altitude } \\
\text { (masl) }\end{array}$ & $\begin{array}{l}\text { Complete } \\
\text { years data }\end{array}$ & $\begin{array}{c}\text { Monthly } \\
\text { missing } \\
\text { data }(\%)\end{array}$ & $\begin{array}{c}\text { Annual } \\
\text { rainfall } \\
(\mathrm{mm})\end{array}$ & Regime & PR \\
\hline 1 & Nuevo Rocafuerte & Napo & 189 & 12 & 45 & 2848 & 22 & 2.4 \\
\hline 2 & Tiputini Aeropuerto & Napo & 219 & 11 & 32 & 2597 & 22 & 2.2 \\
\hline 3 & Tena & Napo & 665 & 16 & 17 & 4428 & 22 & 1.9 \\
\hline 4 & Papallacta & Napo & 3150 & 21 & 8 & 1423 & 22 & 2.9 \\
\hline 5 & Reventador & Napo & 1145 & 8 & 58 & 6172 & 22 & 1.4 \\
\hline 6 & Archidona & Napo & 630 & 22 & 13 & 4237 & 22 & 1.9 \\
\hline 7 & Zatzayacu (Arosemena Tola & Napo & 628 & 18 & 13 & 4767 & 22 & 1.9 \\
\hline 8 & Borja-Mision Josefina & Napo & 1500 & 18 & 17 & 2683 & 22 & 2.0 \\
\hline 9 & Loreto & Napo & 420 & 17 & 45 & 1865 & 12 & 2.9 \\
\hline 10 & Rumipamba-Salcedo & Pastaza & 2680 & 29 & 0 & 579 & 12 & 3.8 \\
\hline 11 & Puyo & Pastaza & 960 & 30 & 0 & 4507 & 21 & 1.6 \\
\hline 12 & Ambato-Granja & Pastaza & 2680 & 22 & 30 & 483 & 11 & 2.7 \\
\hline 13 & Banos & Pastaza & 1846 & 21 & 3 & 1295 & 22 & 3.7 \\
\hline 14 & Sangay (Puerto Santa Ana) & Pastaza & 880 & 21 & 10 & 4008 & 21 & 1.6 \\
\hline 15 & Riobamba Aeropuerto & Pastaza & 2760 & 25 & 8 & 436 & 11 & 3.8 \\
\hline 16 & Pastaza Aeropuerto & Pastaza & 1038 & 19 & 33 & 5211 & 21 & 1.6 \\
\hline 17 & Latacunga Aeropuerto & Pastaza & 2782 & 2 & 4 & 475 & 11 & 4.3 \\
\hline 18 & Pujili (4 Esquinas) & Pastaza & 3230 & 20 & 27 & 618 & 11 & 4.9 \\
\hline 19 & La Granga- Chimborazo & Pastaza & 2720 & 20 & 27 & 574 & 11 & 3.3 \\
\hline 20 & Pillaro & Pastaza & 2805 & 26 & 2 & 658 & 21 & 2.1 \\
\hline 21 & Guaslan & Pastaza & 2850 & 26 & 1 & 627 & 11 & 3.8 \\
\hline 22 & Guaytacama & Pastaza & 3075 & 24 & 8 & 510 & 11 & 5.5 \\
\hline 23 & Cusubamba & Pastaza & 2990 & 26 & 1 & 567 & 11 & 5.1 \\
\hline 24 & Pilahuin & Pastaza & 3360 & 28 & 1 & 673 & 22 & 1.9 \\
\hline 25 & Tisaleo & Pastaza & 3250 & 26 & 1 & 705 & 22 & 2.1 \\
\hline 26 & Huambalo & Pastaza & 2880 & 26 & 5 & 821 & 22 & 2.8 \\
\hline 27 & San Juan Chimborazo & Pastaza & 3220 & 24 & 3 & 673 & 11 & 6.6 \\
\hline 28 & Alao & Pastaza & 3200 & 23 & 3 & 1051 & 22 & 2.8 \\
\hline 29 & Palmira Inamhi & Pastaza & 3180 & 22 & 10 & 578 & 11 & 5.7 \\
\hline 30 & La Arge lia-Loja & Santiago & 2160 & 29 & 1 & 914 & 12 & 3.4 \\
\hline 31 & Cuenca Aropuerto & Santiago & 2516 & 24 & 7 & 801 & 11 & 3.8 \\
\hline 32 & Paute & Santiago & 2289 & 28 & 2 & 734 & 12 & 2.6 \\
\hline 33 & Gualaceo & Santiago & 2230 & 19 & 6 & 737 & 12 & 3.4 \\
\hline 34 & El Labrado & Santiago & 3335 & 26 & 3 & 1262 & 21 & 1.8 \\
\hline 35 & Gualaquiza Inamhi & Santiago & 750 & 15 & 46 & 1957 & 22 & 2.4 \\
\hline 36 & Zamora & Santiago & 970 & 21 & 9 & 1936 & 21 & 1.5 \\
\hline 37 & Cumbe & Santiago & 2720 & 28 & 2 & 668 & 11 & 2.6 \\
\hline 38 & Giron & Santiago & 2130 & 28 & 1 & 773 & 12 & 15.2 \\
\hline 39 & Ricaurte-Cuenca & Santiago & 2545 & 23 & 2 & 897 & 11 & 4.7 \\
\hline 40 & San Lucas Inamhi & Santiago & 2525 & 18 & 7 & 1128 & 21 & 2.1 \\
\hline 41 & Mendez Inamhi & Santiago & 665 & 15 & 30 & 2160 & 22 & 2.1 \\
\hline 42 & San Francisco-San Ramon & Santiago & 1620 & 20 & 7 & 2272 & 22 & 2.8 \\
\hline 43 & Cochapamba-Quingeo & Santiago & 2760 & 14 & 47 & 740 & 12 & 4.3 \\
\hline 44 & Pindilig & Santiago & 270 & 18 & 42 & 1131 & 22 & 2.7 \\
\hline 45 & Huaysimi & Santiago & 950 & 11 & 50 & 2346 & 21 & 1.4 \\
\hline 46 & Yacuambi en La Paz & Santiago & 980 & 9 & 73 & 2800 & 21 & 1.7 \\
\hline 47 & Yaupi & Santiago & 380 & 5 & 84 & 3604 & 21 & 1.6 \\
\hline
\end{tabular}

The Pluviometric Ratio (PR) and the Hydrological Ratio (HR) correspond to the ratio between maximum and minimum monthly values during the year. They give a first indication about seasonal variability. When the index value is close to 1 , the seasonal variability is very low. When the index value is greater than 1 , seasonality increases.

The hydrographical network [shown in Figs. 1, 2, (and 10)] was drawn up by digitalization of a mosaic of Japanese Earth Resources Satellite-1 (JERS-1) sat- 


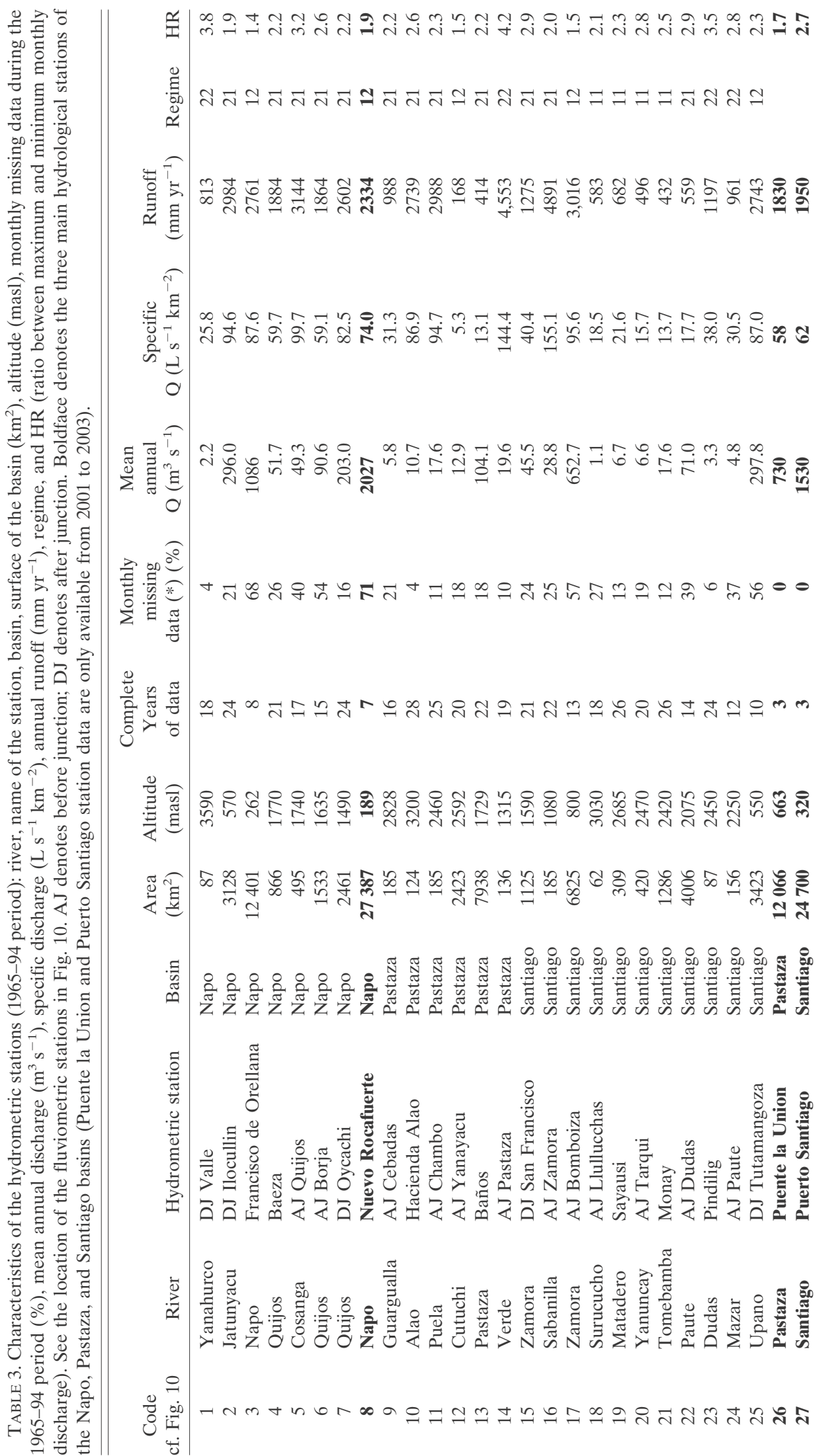


ellite images, with a density of about $0.15 \mathrm{~km} \mathrm{~km}^{-2}$ (Muller et al. 1999). In Figs. 2, 3 (and 10), the limit and extent of the subriver basins were obtained by extracting the topographic limits of the Andean and Amazonian river basins from the Shuttle Radar Topography Mission (SRTM) map (L. Mialocq et al. 2005, unpublished manuscript).

A Geographical Information System (GIS) derived from the SRTM map is used to monitor the geographical variations of hydropluviometric regimes and to draw up an isoyets map.

The vertically integrated water vapor flux is derived from the specific humidity and the horizontal wind between the ground and $200 \mathrm{hPa}$ (Rao et al. 1996). It is used to suggest explanations for the regimes that have not been described yet. Data originate from the National Centers for Environmental Prediction-National Center for Atmospheric Research (NCEP-NCAR) project of the National Oceanic and Atmospheric Administration (NOAA) (Kalnay et al. 1996). Reanalysis data result from a short-term operational forecast model and from taking into account observations from various sources (land, ship, aircraft, satellite, etc.). Data are provided 4 times a day, on a $2.5^{\circ}$ latitude $\times 2.5^{\circ}$ longitude global grid, at 17 pressure levels and longterm monthly means derived from data for the 1968-96 period.

The definition of rainfall and discharge regimes is obtained by classifying the monthly mean values of the different stations. Monthly mean values are rainfall and discharge indices computed monthly to classify the stations according to their annual cycle and not to an amount of water. For the month considered, the rainfall index is the monthly rainfall divided by one-twelfth of the annual rainfall. The hydrometric monthly discharge index (HMDI) is the mean monthly discharge divided by the annual discharge. A cluster analysis based on a Hierarchical Ascending Classification (HAC) is used to obtain an objective classification. The Ward criteria are applied to maximize interclass variance (Ward 1963).

The Chi square test measures the relationship between two qualitative variables whose crossed modalities are counted in a contingency table. This test is employed to verify whether rainfall or discharge regime types are related to some geographical characteristics of the stations: watershed (Napo, Pastaza, and Santiago), mean altitude, and size of the basin.

\section{Rainfall and discharge regimes in the Ecuadorian Amazon basin: Results and discussion}

Thanks to the newly available dataset described in section 3, a new spatial rainfall distribution is proposed and the main characteristics of the Ecuadorian Amazon Basin rivers are described. Then, rainfall and discharge regimes are defined and the spatial distribution of discharge regimes is related to that of rainfall regimes.

\section{a. Rainfall distribution and rainfall regimes}

The mean annual precipitation in the Amazon basin of Ecuador is $2800 \mathrm{~mm}$ (Armijos 2002). This value, which is one of the highest for large river basins, can be accounted for by the high specific humidity and convection in this region, by the orographic lifting of moist air that produces high amounts of rain on the Andes piedmont, and by the large-scale concave shape of the Andes that promotes enhanced low-level convergence (Figueroa and Nobre 1990). An annual isoyets map for the three largest Amazon basins of Ecuador, covering the 1965-94 period, is given in Fig. 3. Despite scarce information for part of the lowland, this map of eastern Ecuador is a more accurate supplement to that of Pourrut (1994). It shows the dependence of rainfall on altitude with decreasing amounts as altitude increases, that is, from more than $4000 \mathrm{~mm}$ in the case of the downstream Napo basin to less than $1000 \mathrm{~mm}$ in the upper Andes. Figure 4 shows that three groups of rainfall stations can be identified, depending mainly on altitude. In stations above 2000 masl (group a), the annual rainfall is relatively low, varying from 500 to $1500 \mathrm{~mm} \mathrm{yr}^{-1}$, as moisture supply and specific humidity are low. This amount is recorded irrespective of altitude and river basin. Downstream, below 1300 masl (group c), annual rainfall is highly variable, from 2000 to $6000 \mathrm{~mm} \mathrm{yr}^{-1}$, and depends on the basin: the stations available are less rainy in the Santiago basin and rainier in the Pastaza basin, and very different values are recorded in the Napo basin. Rainfall increases with altitude in the Napo and Pastaza basins and a maximum is found at approximately 1000-1500 masl, as observed in Bolivia (Guyot 1993; Ronchail and Gallaire 2006) and Peru (Espinoza et al. 2006). This increase is associated with the uplift of moist air in the first slopes of the Andes. The elevation of maximum rainfall is different from what Pulwarty et al. (1998) described in the southeastern Venezuelan Andes, where maximum rainfall occurs at sea level elevation. In group b, between 1300 and 2000 masl, annual rainfall is about $2000 \mathrm{~mm} \mathrm{yr}^{-1}$. The overall rainfall decrease with altitude seems to vary from one river basin to another. A low gradient is observed in the Pastaza basin and a strong one along the Santiago basin. However, this may be due to the imperfect station sampling related to different topographic features of the basins: high terrains (above 500 masl) are mainly found in the southern basins (99\% for Santiago basin and $69 \%$ for Pastaza basin) rather than in the Napo 


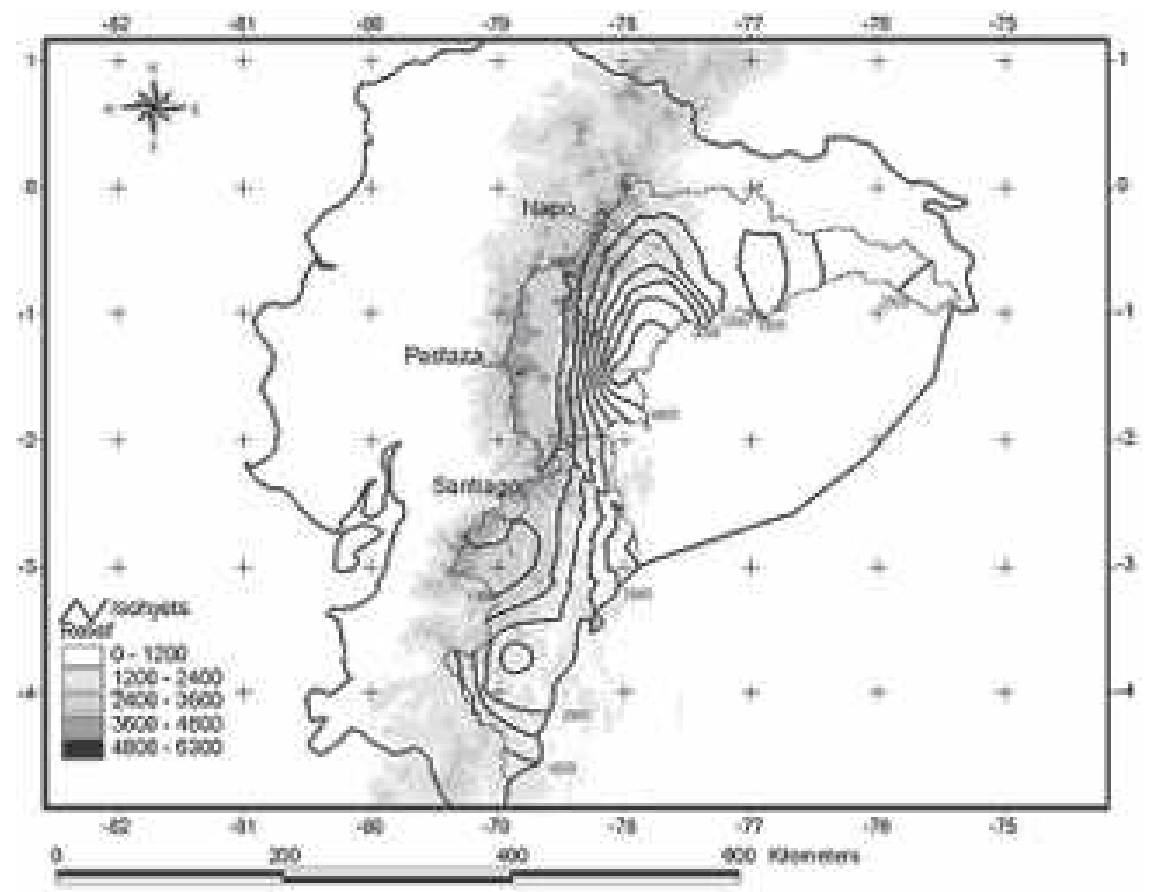

FIG. 3. Annual isoyets map of the three biggest Amazon basins of Ecuador studied in this paper. The isoyet lines are in $\mathrm{mm} \mathrm{yr}^{-1}$ (1965-94 period). Altitude is in masl.

basin $(45 \%)$. The numbers and percentages of Andean stations are higher in the Santiago and Pastaza basins and lower in the Napo basin. Thus, a general altitude versus rainfall gradient cannot be proposed for the Amazon basin of Ecuador.

In the Napo basin, the only basin with the same

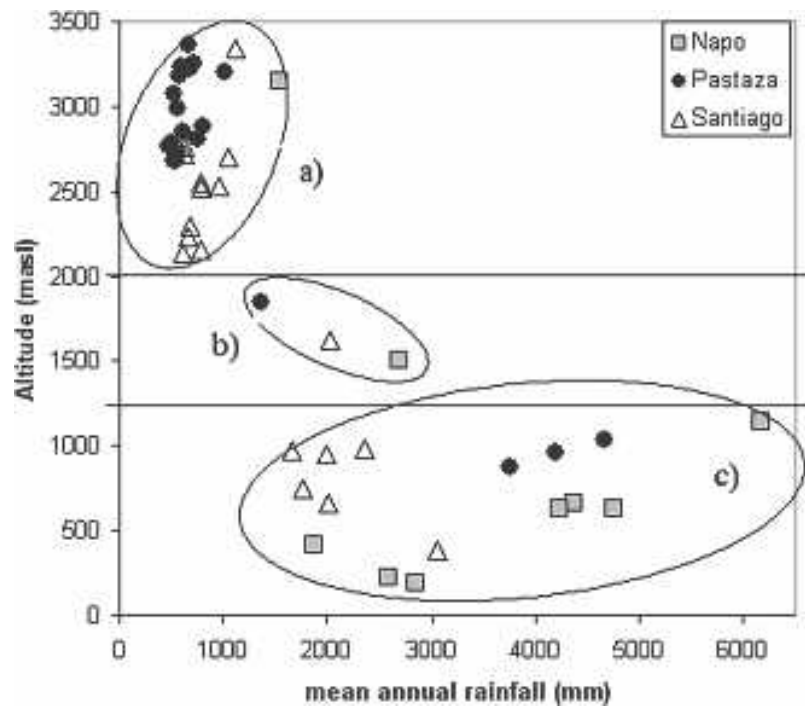

FIG. 4. Mean annual rainfall (mm) vs altitude (masl) in the Napo, Pastaza, and Santiago River basins (1965-94 period). The comments about the three groups of stations a, b, and $\mathrm{c}$ are in the text in section $4 \mathrm{a}$. amount of surfaces in the Andes and in the lowlands, rainfall clearly varies from east to west. In lowland stations 1, 2, and 9 (Table 2 and Fig. 2), in the Amazonian plain, rainfall is about 1850 to $2850 \mathrm{~mm} \mathrm{yr}^{-1}$. In Tena (station 3), Archidona (station 6), and Zatzayacu (station 7), situated approximately at 650 masl on the first slopes of the Andes, the forced air uplift provides high rainfall, around $4500 \mathrm{~mm} \mathrm{yr}^{-1}$. Then, rainfall diminishes as altitude increases and moist air declines, as in the Papallacta station (station 4, 3000 masl, $1400 \mathrm{~mm}$ $\mathrm{yr}^{-1}$ ).

Nevertheless, the extreme spatial variation of annual rainfall is not only related to altitude. The position of the station on the humid windward side or on the leeward side of the cordillera and the orientation of the valleys are also very important. For example, in the Napo basin, two stations feature opposite behaviors: Reventador (station 5) records $6170 \mathrm{~mm} \mathrm{yr}^{-1}$ at 1150 masl and Borja-Mision Josefina (station 8) records 2680 $\mathrm{mm} \mathrm{yr}^{-1}$ at 1500 masl. The main difference between both stations lies in their position: Reventador is on the eastern slope of the eponymous volcano, facing the humid easterlies, while Borja-Mision Josefina lies on a slope exposed to the west and sheltered from humid winds. The lowest rainfall value is in Riobamba (436

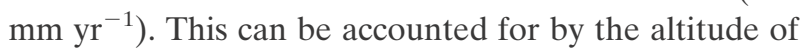
the station (2760 masl) and its location in a deeply embanked valley, sheltered from the eastern winds by the 
eastern cordillera. Conversely, nearby stations 11, 14, and 16, at a lower altitude (900-1000 masl) and on eastward slopes, are very rainy (4000 to $5000 \mathrm{~mm} \mathrm{yr}^{-1}$ ).

Still in the Pastaza basin (Fig. 2), stations 10, 12, 17, $18,19,20,21,22,23,24,25,26$, and 28, located over 2680 masl feature an annual rainfall between 470 and $1050 \mathrm{~mm}$. The low rainfall may be related to the altitude and to the position in valleys sheltered from easterly moist wind by the north-northeast-southsouthwest Cordillera Real. In the Santiago basin, some low (660 to 1600 masl) stations $(35,36,41,45$, and 46) have relatively low annual amounts (1930 to $2800 \mathrm{~mm}$ $\mathrm{yr}^{-1}$ ) compared with Napo basin stations (3, 6, and 7), which are very rainy (in excess of $4200 \mathrm{~mm} \mathrm{yr}^{-1}$ ), despite being located at the same altitude. In the Santiago basin, the north-south Cutucu and Condor Cordilleras protect the rain gauge stations from easterly winds. Conversely, on the other side of the Cutucu Cordillera, station 47 at 380 masl registers $3604 \mathrm{~mm} \mathrm{yr}^{-1}$.

Finally, the mean rainfall computed by basin using the Thiessen method shows a global rainfall decrease from north to south, with $3100 \mathrm{~mm} \mathrm{yr}^{-1}$ in the Napo basin, $2300 \mathrm{~mm} \mathrm{yr}^{-1}$ in the Pastaza basin, and $2000 \mathrm{~mm}$ $\mathrm{yr}^{-1}$ in the Santiago basin. This north-south gradient may be related to the north-south increasing percentage of high terrains. Moreover, the north-south orientation of valleys where the rainfall gauges are located in the Santiago basin account for their leeside position and reduced rainfall.

Rainfall regimes in the Napo, Pastaza, and Santiago basins are first examined by looking at the entire set of data, per basin. Pluviograms of nine stations between 190 and 3150 masl in the Napo basin show that different regimes coexist (Fig. 5a). For example, in Papallacta, an Andean station (3150 masl) with a unimodal regime, the rainfall maximum coincides in July with a dry period in Loreto, a station with two maxima (AprilNovember) located in the Andean foothills (420 masl). In the Pastaza basin (Fig. 5b), stations with a unimodal regime, mostly on the eastern slopes of the Andes, can be found between 1800 and 3200 masl. Two other sets of stations with two rainfall maxima are situated in the upper Andes and the Amazon plain, respectively. Different regimes can also be found in the Santiago basin (Fig. 5c). For example, Pindiling and CochabambaQuingeo stations, which are at the same altitude (around 2700 masl), exhibit a unimodal and a bimodal regime, respectively, and the June maximum in Pindilig coincides with the minimum annual rainfall in Cochabamba-Quingeo station. Furthermore, a bimodal regime in the Andes is frequent and well defined, while in lower regions, a high rainfall maximum in March-May is followed by a low peak around October. On the con-
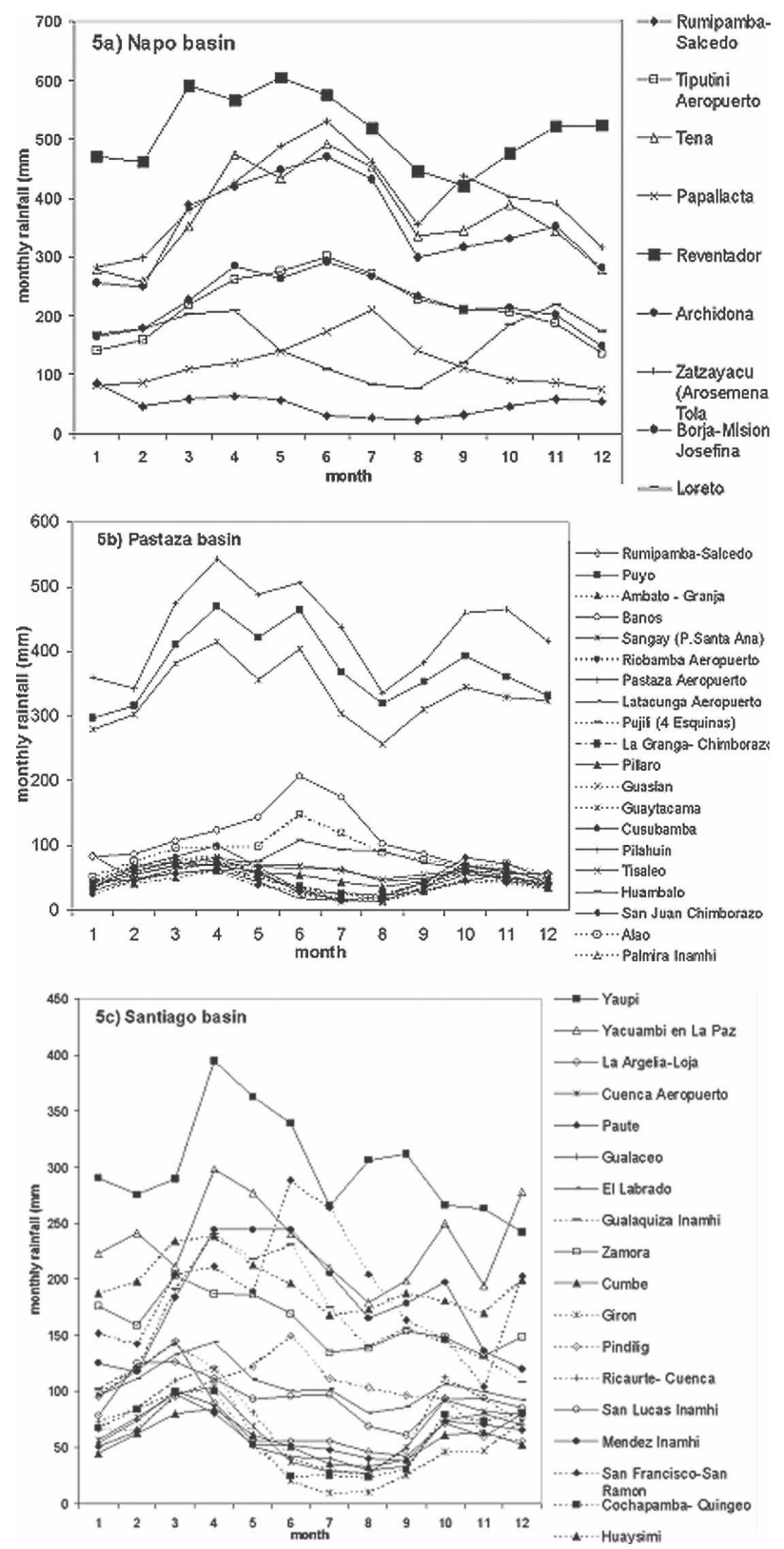

FIG. 5. Mean monthly rainfall $(\mathrm{mm})$ in the stations of the Ecuadorian Amazon basins during the 1965-94 period: (a) Napo, (b) Pastaza, and (c) Santiago.

trary, amongst these rainy stations, San Francisco-San Ramon exhibits a high maximum in June-July.

Seasonal rainfall variability, measured by the PR (see Table 2), tends to decrease with an increase in average interannual precipitations (Fig. 6; to facilitate reading, the extreme 15.2 PR value of the Giron station is not shown). Generally, the highest rainfall values are associated with regular pluviometric regimes and are more frequent in the plain. However exceptions can be found. For example, in the Napo basin, Reventador 


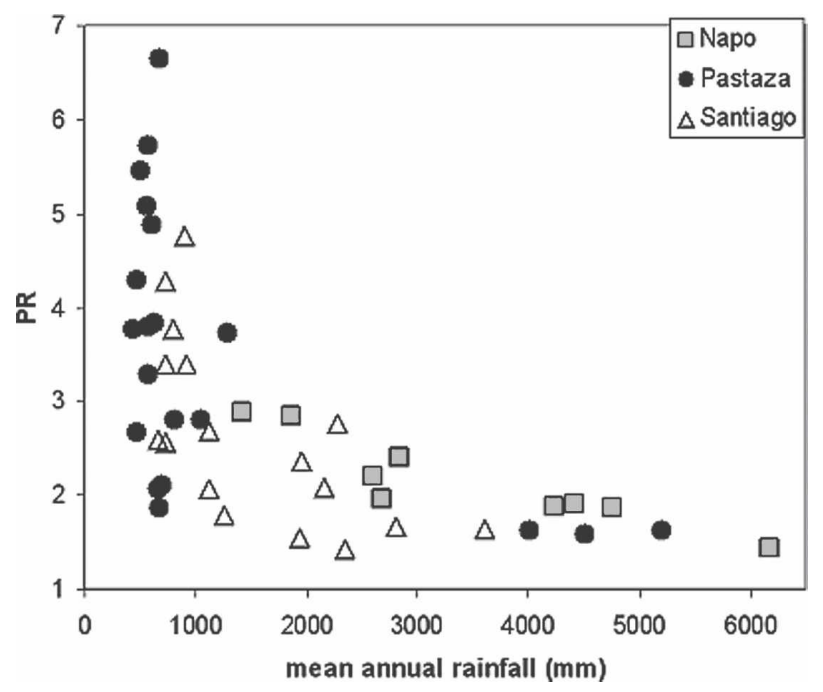

FIG. 6. PR (quotient between maximum and minimum monthly rainfall in $\mathrm{mm}$ ) vs mean annual rainfall $(\mathrm{mm})$ in the Napo, Pastaza, and Santiago River basins (1965-94 period). Values are listed in Table 2.

features a lower PR value (1.4 at 1145 masl) than Loreto (2.9 at 420 masl). PR values in the mountainous Pastaza basin are highly variable (1.6 to 6.6 ). The maximum PR value per basin rises from the north to the south, from 3 (Napo basin) to 7 (Pastaza basin) and 15 (Santiago basin; not shown in Fig. 6), while minimum $\mathrm{PR}$ values remain the same in all basins. The low rainfall variability in the lowlands is also observed at the interannual time scale (Rossel 1997).

To better assess the regime diversity observed in Fig. 5, an HAC based on monthly rainfall indices of 47 rainfall stations is performed using the Ward criteria and Euclidian distance. The HAC separates the set of stations into two main clusters that, in turn, can be divided into two subclusters (Fig. 7). In cluster 1 (20 stations out of 47), two rainfall maxima, after the equinox, in April and October, are separated by two minima, around the solstices, in July-August and December-January, the first minimum being more pronounced than the second one (Fig. 8). In this cluster, rainfall seasonality is stronger (3 times higher values between the rainiest and driest seasons) than in cluster 2 (doubled values between the rainiest and driest seasons). In cluster 1-1, the maximum (minimum) values are slightly higher (lower) than in cluster 1-2, featuring a stronger seasonal difference. Moreover, the first maximum is in April in cluster 1-1 and in March cluster 1-2. In cluster 2 (27 stations out of 47), rainfall variability during the year is lower (Fig. 8). However, relative peaks can be identified in April, June, and October. In cluster 2-1, the April peak is more pronounced than in July and it is the opposite in

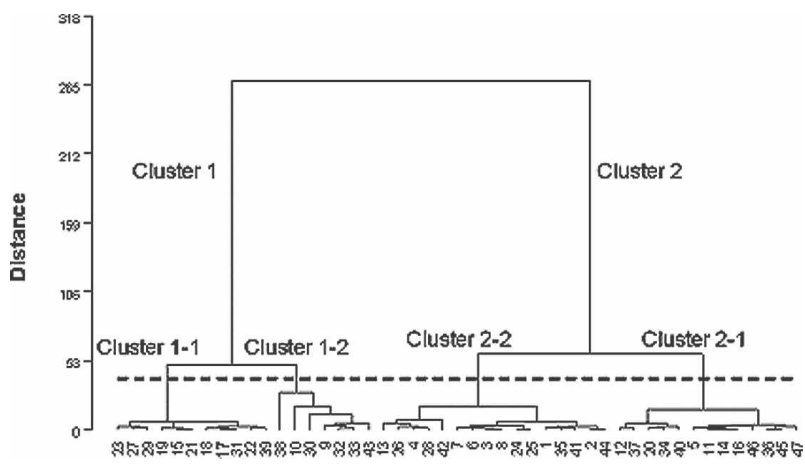

FIG. 7. Dendogram resulting from an HAC of the stations characterized by their monthly rainfall indexes. On the $x$ axis are the codes of the stations (see Table 2) and on the $y$ axis is the aggregation distance. The dashed line shows the truncation of the hierarchical tree.

cluster $2-2$. In cluster $2-1$, the October secondary maximum is stronger than in cluster 2-2. In both clusters, relative minima are registered in August and in December-January.

Chi square tests are performed to assess whether rainfall regimes depend on the altitude of the stations and on the basin to which they belong (Napo, Pastaza, and Santiago). To apply the Chi square test, altitude has been discretized into four classes. Relationships between rainfall regimes and these variables are significant at the 99\% level (Table 4). They show that stations with a bimodal regime, belonging to cluster 1 (1-1 or 1-2), are mainly found at high altitude, over 2000 masl, in the westernmost regions (Fig. 2). As high stations are mainly located in the Pastaza and Santiago basins, cluster 1 stations are generally found in these basins. Regime 1-2 is mainly observed in the southernmost Santiago basin. Toward the east, at a lower altitude, stations with a lower rainfall cycle (cluster 2) can be found (Fig. 2). However, the reverse is not true as $30 \%$ to $40 \%$ of cluster 2 stations are located higher than 2000

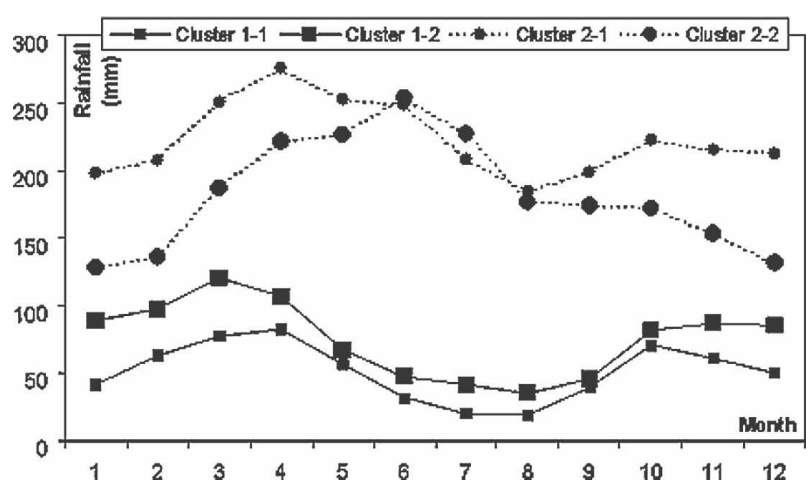

FIG. 8. Rainfall regimes $(\mathrm{mm})$ resulting from an HAC. 
TABLE 4. (a) Altitudinal and (b) per basin distribution of the rain gauge stations as a function of the rainfall regime cluster (values are in percentage and altitudes are in masl).

(a)

\begin{tabular}{cccccc}
\hline \multirow{2}{*}{$\begin{array}{c}\text { Rainfall } \\
\text { regime }\end{array}$} & $0-1000$ & $1000-2000$ & $2000-3000$ & $3000-4000$ & Total \\
\cline { 2 - 6 } & 0 & 0 & 64 & 36 & 100 \\
11 & 14 & 0 & 86 & 0 & 100 \\
12 & 50 & 8 & 33 & 8 & 100 \\
21 & 44 & 19 & 13 & 25 & 100
\end{tabular}

(b)

\begin{tabular}{ccccc}
\hline \multirow{2}{*}{$\begin{array}{c}\text { Rainfall } \\
\text { regime }\end{array}$} & \multicolumn{4}{c}{ Basin } \\
\cline { 2 - 5 } & Pastaza & Napo & Santiago & Total \\
\hline 11 & 82 & 0 & 18 & 100 \\
12 & 14 & 14 & 71 & 100 \\
21 & 42 & 0 & 58 & 100 \\
22 & 31 & 44 & 25 & 100 \\
\hline
\end{tabular}

masl. Regime $2-1$ is often observed at a lower elevation (below $2000 \mathrm{~m}$ ) and in the Santiago and Pastaza basins. Regime $2-2$ presents some ubiquity as observed at any altitude.

Bimodal rainfall regimes with a strong (regime 1) or a low (regime 2-1) annual cycle are related to intense warming and convection after the equinox and to enhanced convection. The rainfall annual cycle is low in the lowlands as specific humidity is important all yearround and convection is always possible. The first March-April maximum is high as the eastern water vapor flux is important $\left(150 \mathrm{~kg} \mathrm{~m}^{-1} \mathrm{~s}^{-1}\right.$ at $\left.2.5^{\circ} \mathrm{S}, 77.5^{\circ} \mathrm{W}\right)$ and zonal in April (Fig. 9b), while it is lower (105 $\mathrm{kg} \mathrm{m}^{-1} \mathrm{~s}^{-1}$ at $2.5^{\circ} \mathrm{S}, 77.5^{\circ} \mathrm{W}$ ) and has a southern component corresponding to the beginning of the south American monsoon in October (Fig. 9d). In May and June, the convection associated with equinoctial radiation maximum decays, but as the water vapor flux is high $\left(215 \mathrm{~kg} \mathrm{~m}^{-1} \mathrm{~s}^{-1}\right.$ at $\left.2.5^{\circ} \mathrm{S}, 77.5^{\circ} \mathrm{W}\right)$ and zonal (Fig. $9 \mathrm{c})$, rainfall remains abundant, especially in stations located on the windward side of the Cordillera. This particular circulation feature gives rise to the original regime 2-2 with a June maximum, mainly noticed in the northern Napo and Pastaza basins where there is neither a large north-south valley nor a strong shelter effect. Moreover, this particular feature explains the juxtaposition, in June, of intra-Andean stations that experiment their rainfall minimum with windward stations on the eastern slopes of the Cordillera that undergo their rainfall maximum. This kind of juxtaposition has already been described in Venezuela by Pulwarty et al. (1992). In January, the vertically integrated water vapor flux is low $\left(55 \mathrm{~kg} \mathrm{~m}^{-1} \mathrm{~s}^{-1}\right.$ at $2.5^{\circ} \mathrm{S}$, $77.5^{\circ} \mathrm{W}$ ) with a strong southward component associated
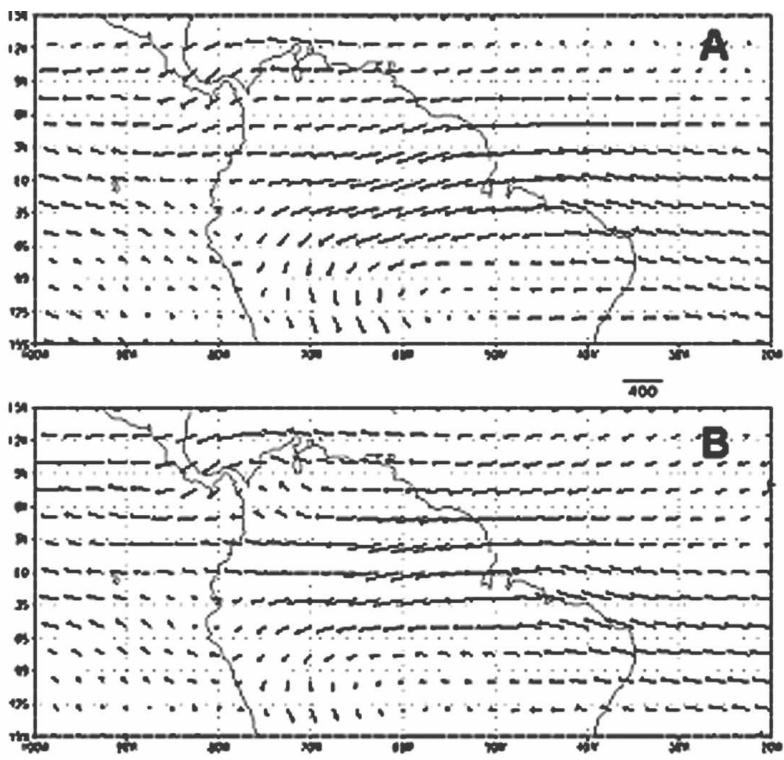

तक

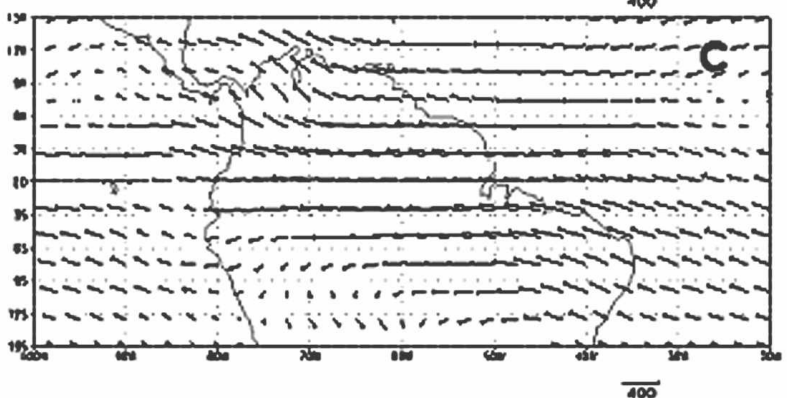

$\overline{100}$

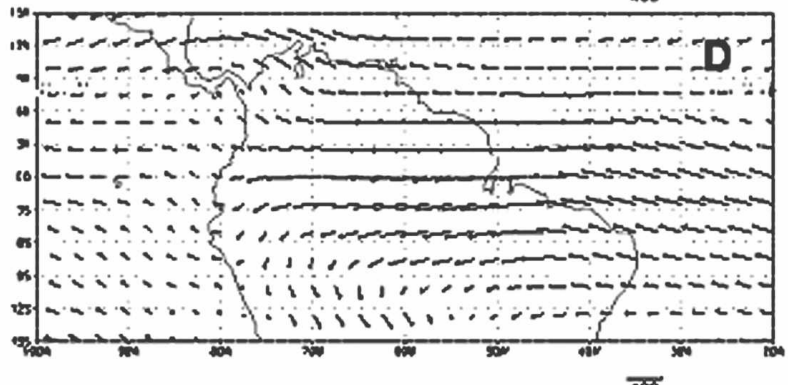

$\overline{\Phi \infty}$

FIG. 9. Mean 1968-96 vertically integrated water vapor flux $\left(\mathrm{kg} \mathrm{m}^{-1} \mathrm{~s}^{-1}\right.$ ) between the ground and 200-hPa wind in (a) January, (b) April, (c) June, and (d) October.

with the South American monsoon that transfers water vapor toward the tropical regions of South America (Fig. 9a). Therefore, very little rain is measured in December-January in all stations.

\section{b. Hydrological means and regimes}

Some hydrological studies and yearbooks focusing on the Andean regions of Ecuador have been established (Erazo and Hoorelbecke 1999; Hoorelbecke and Perez 1999; Hoorelbecke et al. 1999; Perez 2000; Moreno and 


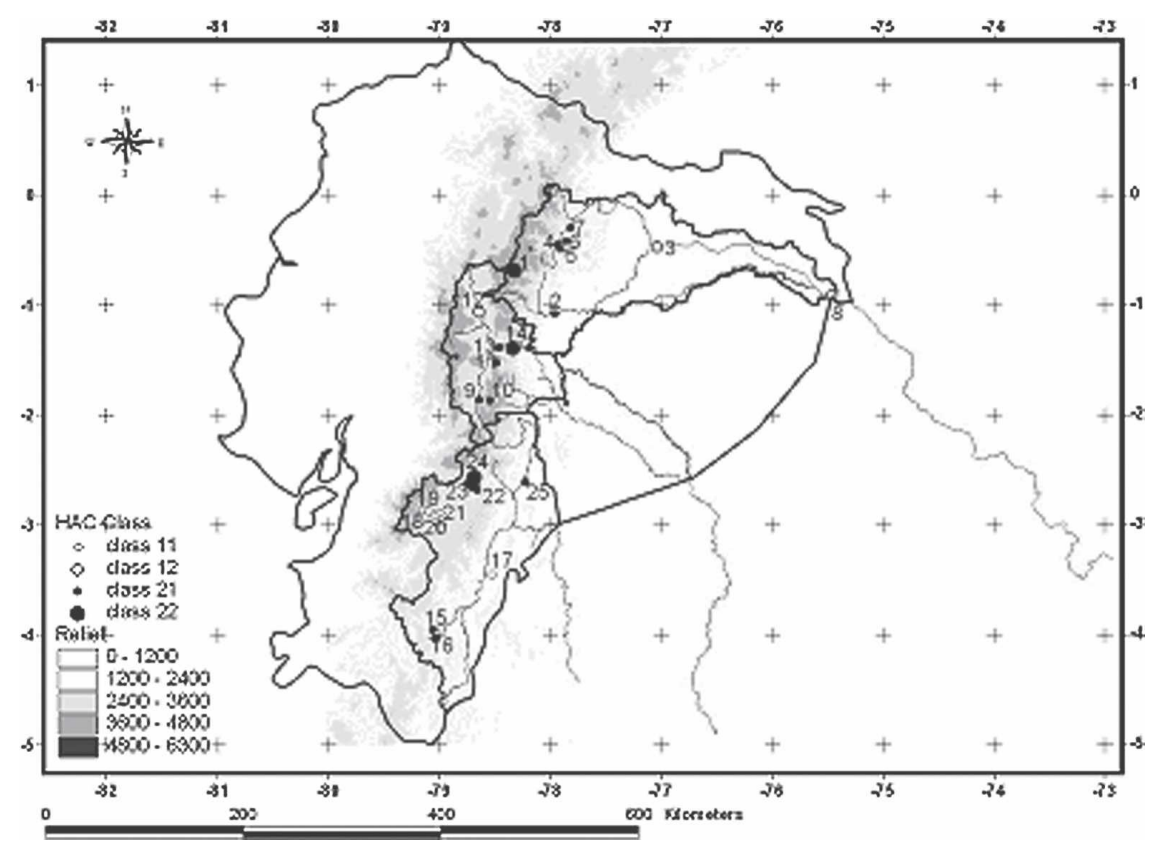

FIG. 10. Hydrometric stations' locations and their regimes resulting from an HAC. Regime 1 has a low seasonality with a relative maximum in April (class 1-1) or in June (class 1-2). The maximum is in July in regime 2, with a low seasonality for class 2-1 and a higher one for class $2-2$. Station codes (numbers) are listed in Table 3. From north to south bold lines underline the limits of the Napo, Pastaza, and Santiago basins. Altitude is in masl.

Tapia 2001), but so far, the Ecuadorian Amazon basin has not been investigated.

The hydrometric stations (Fig. 10) are distributed throughout the eastern mountain range (22 stations) and in the lowlands ( 5 stations below 550 masl). They are located in the three main river basins between 190 and 3600 masl and they control river basins that cover areas from 41 to $27000 \mathrm{~km}^{2}$. The Napo is the biggest eastern basin (in terms of size and annual discharge), followed by the Santiago and the Pastaza basins. Altogether, a water volume of about $153 \times 10^{9} \mathrm{~m}^{3}$ (i.e., 4800 $\left.\mathrm{m}^{3} \mathrm{~s}^{-1}\right)$ is exported annually through these stations. This total has been estimated using the average discharge of the main stations downstream from the three basins.

In the 27 eastern basins, the specific discharge (qs) shows great spatial irregularity with values from 5.3 [subbasin of Cutuchi in Antes de la Junta (A.J.) Yanayacu station in the Pastaza basin] to $155 \mathrm{~L} \mathrm{~s}^{-1} \mathrm{~km}^{-2}$ (185 $\mathrm{km}^{2}$ subbasin of Sabanilla at the A.J. Zamora station in the Santiago basin; Table 3). The importance of the latter value corresponds to a very rainy microclimate. For comparison purposes, Guyot et al. (1996) found a $140 \mathrm{~L} \mathrm{~s}^{-1} \mathrm{~km}^{-2}$ qs value in a basin in Bolivia with a similar area $\left(160 \mathrm{~km}^{2}\right)$. This basin is situated in the Chapare region, one of the wettest Amazonian basins, with $4000 \mathrm{~mm} \mathrm{yr}^{-1}$ of precipitation in the Amazon foot- hills of the Oriental Cordillera of Andes. The lowest qs values are found in the Andean area (between 5 and 80 $\mathrm{L} \mathrm{s}^{-1} \mathrm{~km}^{-2}$ at an altitude greater than 1500 masl), while the highest are in the foreland and the Amazonian Plain (between 80 and $155 \mathrm{~L} \mathrm{~s}^{-1} \mathrm{~km}^{-2}$ at an altitude lower than 1500 masl; Fig. 11). Specific discharge (qs), like rainfall, generally increases while altitude decreases (Laraque et al. 2004b). Though Fig. 11 shows it, it is difficult to find a relationship between qs and altitude when considering the qs values of the Napo basin, But in this basin, below 500 masl, qs decreases when

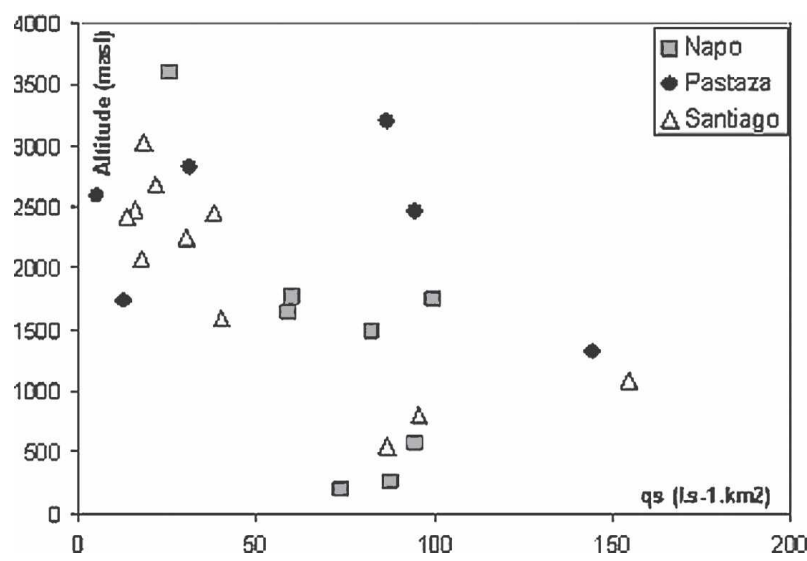

FIG. 11. Specific discharge (qs in $\mathrm{L} \mathrm{s}^{-1} \mathrm{~km}^{-2}$ ) vs altitude (masl) in the Napo, Pastaza, and Santiago River basins (cf. Table 3). 

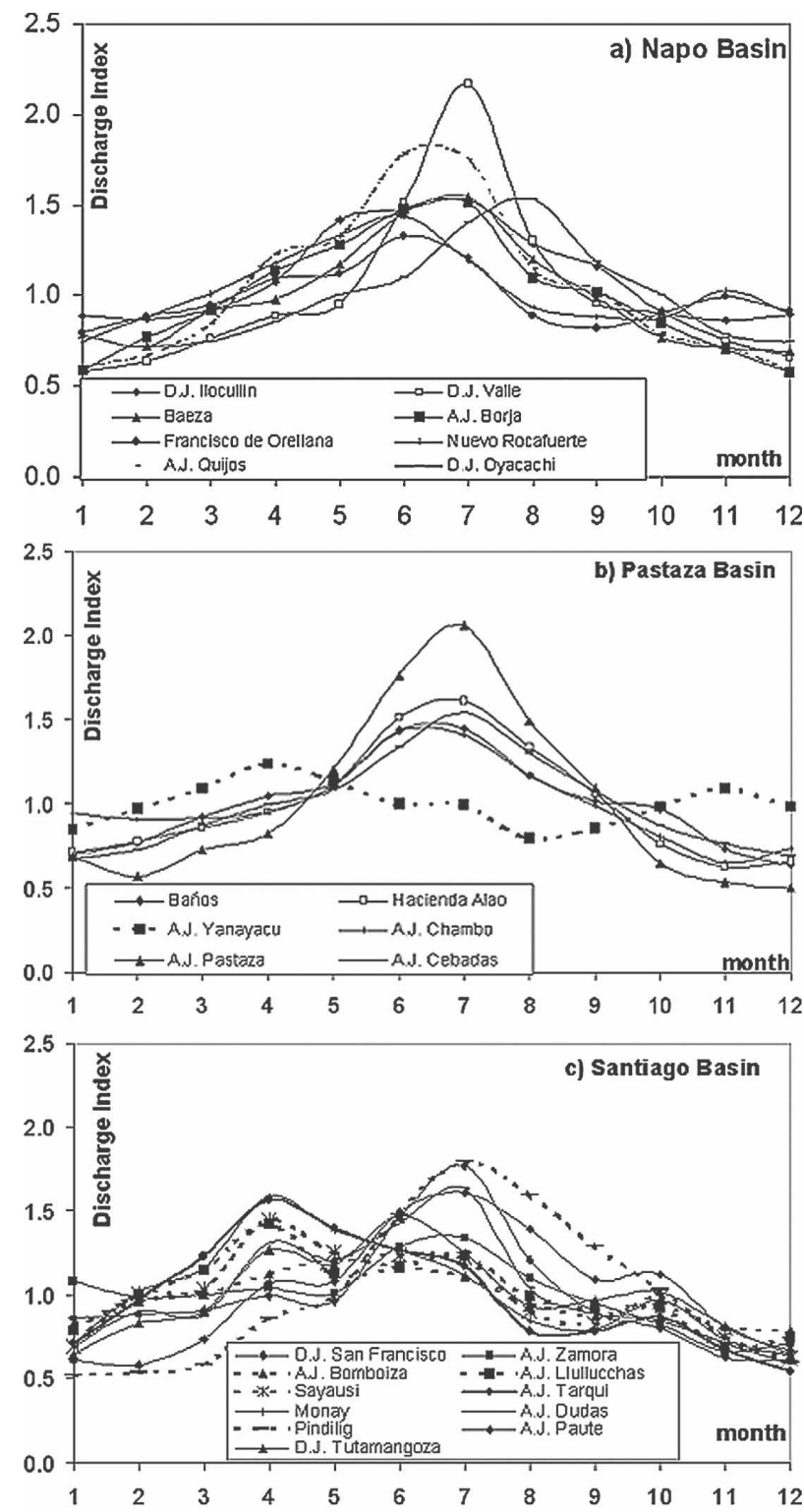

FIG. 12. Some hydrological regimes in the (a) Napo, (b) Pastaza, and (c) Santiago River basins. For each month, the discharge index is the monthly discharge divided by the annual discharge. AJ denotes before junction and DJ denotes after junction.

altitude decreases. For example, qs decreases from 95 to 87 and $74 \mathrm{~L} \mathrm{~s}^{-1} \mathrm{~km}^{-2}$, respectively, for the Illoculin station (500 masl), Franscisco de Orellana station (262 masl), and Nuevo Rocafuerte station (189 masl) in the Napo basin.

The discharge regimes are first analyzed looking at the monthly hydrograms of the three great eastern river basins (Fig. 12). In the Napo basin (Fig. 12a), discharge regime tends to be unimodal in the upper stations with a maximum in June-July and a minimum in DecemberJanuary. In the lowlands, the first peak in June-July is
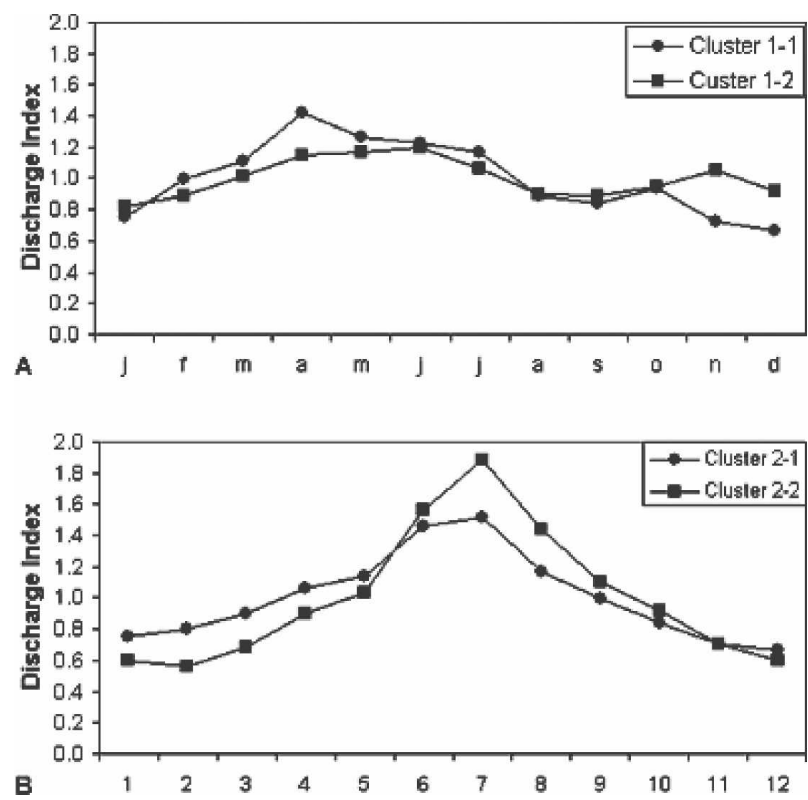

FIG. 13. Hydrological regimes resulting from an HAC of monthly discharge indexes: (a) cluster 1 and (b) cluster 2. For each month, the discharge index is the monthly discharge divided by the annual discharge.

followed by a much smaller one in October-November. In the Pastaza basin (Fig. 12b), a similar feature can be observed at high elevation. However, at $2592 \mathrm{~m}$, the Rio Cutuchi at the Yanayacu station is an exception, as it shows a well-defined bimodal regime, with a first maximum in April and a second in November. As no lowland station is available, no comparison can be made with the Napo basin. In the Santiago basin (Fig. 12c), discharge values tend to increase in April, July, and October in some Andean stations (Llullucchas, Tarqui, and Sayausi). In others, a unique July peak can be observed (Pindiling). Downstream, the same diversity is found, and at the exit (the Bomboisa station at 800 masl), a very low variability can be noticed with a maximum in May and a second one in October.

Seasonal hydrometric variability, described by the HR, ranges from 1.4 to 4.2 in the eastern Ecuadorian hydrometric network (Table 3). There is no apparent relation between the HR and the drained area, or with annual or specific discharge.

A hierarchical ascending classification is employed to identify objectively the main discharge regimes (Fig. 13). It is applied to monthly discharge indexes in order to classify the stations as a function of their variability during the year and not of water fluxes. Two welldifferentiated clusters can be described, as in the case of precipitations. They are divided into two subclusters. Cluster 1 shows a low seasonal variability with a maximum in April and June and a low one in October (Fig. 
TABLE 5. Per basin size distribution of the hydrometric stations as a function of the discharge regime cluster (values are in percentage and basin surface in $\mathrm{km}^{2}$ ).

\begin{tabular}{crrcc}
\hline \hline \multirow{2}{*}{$\begin{array}{c}\text { Discharge } \\
\text { regime }\end{array}$} & $<200$ & $200-1000$ & $1000-5000$ & $>10000$ \\
\cline { 2 - 5 } & 25 & 50 & 25 & 0 \\
11 & 0 & 0 & 40 & 60 \\
12 & 29 & 21 & 36 & 14 \\
21 & 100 & 0 & 0 & 0 \\
22 & & & & \\
\hline
\end{tabular}

13a). Cluster 1-1 has a stronger peak in April, while cluster 1-2 presents an April-June peak. The lowest values are in December-January and second largest are in August-September. Cluster 2 shows a more pronounced seasonality with high discharge values in July and low values from November to February (Fig. 13b). Seasonality is stronger in cluster 2-2. A Chi square test is employed to analyze the relationships between regime types and geographical features like the basin (Napo, Pastaza, or Santiago), the mean altitude, and the size of the basin (Table 5). To apply the Chi square test, the mean altitude and the size of the basin have been discretized into three and four classes of values, respectively. The regime is independent of the basin and of the mean altitude. However, there is a significant relationship (at the $95 \%$ level) between regime and size of the basin.

Regime 1-1 is observed at high altitude in small to medium basins in the upper Santiago basin (points 18 to 21 in Fig. 10) in a south-southwest-north-northeastoriented Andean valley inside the eastern Cordillera. The relative discharge peaks in April and secondlargest amounts in October are concomitant with the rainfall peaks in this region (Figs. 2 and 8). However, while rainfall diminishes sharply in June-July, discharge remains at a high level. This particular regime feature may be related to the presence of hanging aquifers in the thick volcanic porous ash layers, in the paramo formation above 3000 masl. Peat of volcanic origin, often several meters deep, covered by its attendant puna vegetation is soaked with rainwater throughout the year. These vast expanses of volcanic ash spongy soils are scattered with numerous lakes, swamps, and bogs. They often cover ancient glacial valleys and exhibit a high propensity for huge water storage. Recent studies (Williams et al. 2001; Buytaert et al. 2002, 2004) have described the characteristics of this original formation and reviewed its impact on the river flow regime. The slow and persistent outlet from these superficial aquifers may help sustain the flow regimes of some basins at high altitude, during the dry season (May to September).
Regime 1-2 is characteristic of large basins. It is observed in Coca (point 3 in Fig. 10) and Nuevo Rocafuerte (point 8) on the downstream Napo River and also in a large inner basin in the region of LatacungaAmbato in the upper Pastaza basin (point 12).

Regime 2 is characterized by a clear July peak and may be related to rainfall regime $2-2$ described in section 4a. It is observed in all basins; it is frequent in the upper Napo and Pastaza basins and is the most widespread regime in our sample of hydrological stations. Discharge regime $2-1$ with a lower seasonal variation is observed at medium and high elevation in the following locations:

- eastward of Quito, in the Napo basin (points 4 to 7 in Fig. 10), along the north-south Quijos River on the western side of the Sumaco volcano, but close to the lowland;

- in the region of Riobamba (points 9 to 13), westward of the Tungunrahua, Altar, and Sangay volcanoes, but in a position opened toward the east thanks to the west-east Pastaza River; and

- along the north-south Zamora River in the southern Santiago basin (points 15 and 16), westward of the little Condor Cordillera and close to the lowland.

Discharge regime 2-2, with a stronger annual cycle, is only located in small basins $\left(<150 \mathrm{~km}^{2}\right)$, at medium to high elevation in some upper basins of the Napo, Santiago, and Pastaza.

To conclude, there exist a basin size and exposuredependent organization of discharge regimes with

- a bimodal regime with a low annual cycle, with a first maximum from April to July and a second one in October in large basins, especially in the lowlands;

- a bimodal regime with maximum in April and October and a sustained streamflow from May to July in high intra-Andean small basins sheltered from the eastern wind by the Eastern Cordillera; and

- a unimodal regime with a maximum in July on the Andean slopes, in small to large basins, from medium to high altitude, in valleys that are toward the east or close to the lowlands.

\section{Conclusions}

The recent availability of hydrological data from the Ecuadorian Amazon basin makes it possible to review the nature and spatial distribution of rainfall and discharge regimes in this poorly documented region.

Analysis has been conducted using 47 rain gauges and 25 hydrometric stations in the Amazon basin of Ecuador (135 $\left.600 \mathrm{~km}^{2}\right)$, from 200 to 6300 masl and over a 30-yr period (1965-94). The stations are situated in 
subbasins that vary in size from 41 to $27000 \mathrm{~km}^{2}$, in the three main basins-from north to south the Napo, Pastaza, and Santiago basins.

Thanks to the newly available dataset, a new annual isoyets map is proposed. We explain the important rainfall and discharge spatial heterogeneity in the Ecuadorian Amazon basin. Furthermore, the rainfall and discharge regimes that characterize this region are highlighted and their unusual spatial variability is equally explained. These features had not been previously described with so many details.

Annual rainfall is very heterogeneous (from 500 to $4000 \mathrm{~mm} \mathrm{yr}^{-1}$ ) and depends mainly on altitude and the exposure to the dominant easterlies. Abundant rainfall (2000-3000 $\mathrm{mm} \mathrm{yr}^{-1}$ ) has been recorded in the Amazon lowlands under 200 masl. The uplift of moist air with the first slopes of the Andes generates a rainfall maximum (4000-5000 $\mathrm{mm} \mathrm{yr}^{-1}$ ) at around 900-1000 masl on windward slopes. Then, rainfall diminishes to less than $500 \mathrm{~mm} \mathrm{yr}^{-1}$, over $2500 \mathrm{masl}$, as the atmosphere gets drier. However, at similar altitudes, significant rainfall variations are linked to the exposure of the stations to easterlies. Stations on an eastward slope and/or located in a valley to the east register twice as many rainfalls than those in a sheltered position, on a westward slope, or along an embanked river and/or in an inner valley parallel to the north-south eastern Cordillera. Discharge also varies a lot. It is marked by a spatial variation of runoff from 5.3 to $155 \mathrm{~L} \mathrm{~s}^{-1} \mathrm{~km}^{-2}$ that is not only dependent on spatial rainfall variability and therefore requires further investigation.

In the lowlands, rainfall and discharge seasonal variability is very low (Fig. 14a). However, a relative maximum is registered in April for rainfall, and in June for discharge; a secondary maximum can be observed in October (rainfall) and November (discharge). These annual cycles are similar to those in northwestern Brazil, described by Figueroa and Nobre (1990) for rainfall and Molinier et al. (1996) for discharge.

In upper intra-Andean basins, the rainfall annual cycle presents a marked bimodal regime, with a main peak in April and a second one in October and two minima in austral winter (June-August) and in December (Fig. 14b). The maxima are related to an increased convection after the equinox and additionally to an enhanced zonal circulation and moisture uplift in April. In small to medium upper basins, the discharge regime reflects the rainfall regime: the two maxima are concomitant with the two rainfall maxima. However, discharge variability during the year is not as strong as that of rainfall; in particular, the marked July-August rainfall decrease is not evidenced in discharge data. The

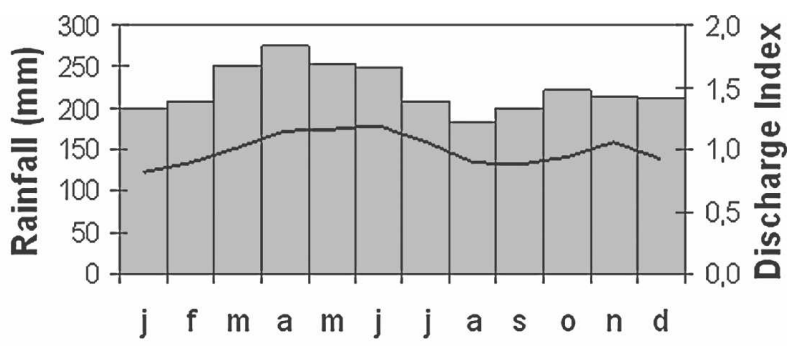

A $\square$ Rainfall Regime 2-1 —Discharge regime 1-2

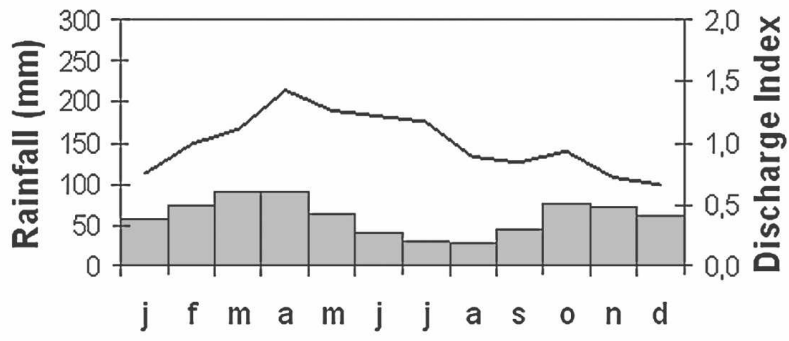

B $\square$ Rainfall regime 1 -Discharge regime 1-1

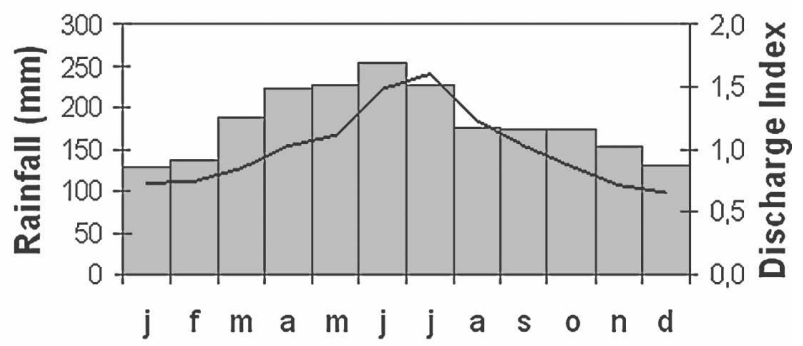

C $\square$ Rainfall regime 2-2 —Discharge regime 2

FIG. 14. Rainfall (bars) and hydrological (lines) regimes in different regions of the Ecuadorian Amazon basin. (a) Lowland stations; (b) Intrabasin Andean stations; and (c) windward Andean stations. Monthly rainfall is in $\mathrm{mm}$. The discharge index is the monthly discharge divided by the annual discharge.

sustained dry season discharge (May to September) may be accounted for by water outflow from the upper Andean "paramo" spongy soils covered with bogs and marshes.

Still in the Andes but at any altitude, a rainfall regime with a low seasonal variability and a relative maximum in July is observed in stations to the east and/or close to the lowlands, mostly in the northern region of the Ecuadorian Amazon basin. The June maximum is linked to a peak in the uplift of moist air. A similar discharge regime with a July peak is observed in basins occupying the same position (Fig. 14c).

To conclude, station exposure accounts for marked differences not only for in annual rainfall amounts, but also in rainfall regime. The juxtaposition in the same 


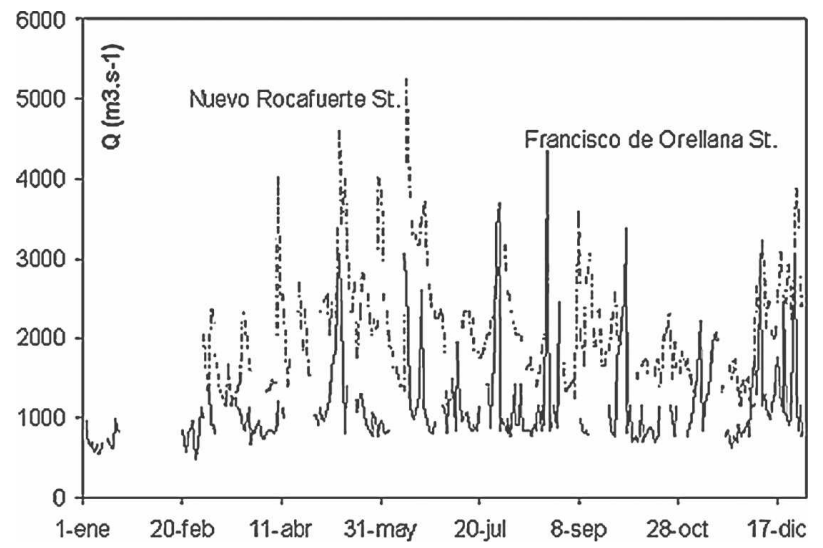

FIG. 15. 2001 daily discharges $\left(\mathrm{m}^{3} \mathrm{~s}^{-1}\right)$ of the Napo River basin: from the foot of the Andes mountains (the Francisco de Orellana station Is denoted by solid line) to the Amazonian plain (the Nuevo Rocafuerte station is denoted by dashed line).

basin of out-of-phase rainfall regimes is a striking feature of the region, particularly during the middle of the year, from March to October. The overlap in different discharge regimes is partly due to the same reason and to the spongy paramo soils. These heterogeneous regimes, along with the frequently low annual cycles in this equatorial region, make it difficult to predict the seasonal flow in the most important eastern rivers of Ecuador. Also, flash floods can be observed almost all year-round (Fig. 15). This is why the major hydric resources $\left(153 \times 10^{9} \mathrm{~m}^{3} \mathrm{yr}^{-1}\right)$ of the Ecuadorian Amazon basin are difficult to monitor and a matter of concern in the context of climate change. It confirms, if needed, the necessity to maintain long-term reliable hydrometeorological networks also dedicated to monitoring sediment transport. This new outlook has already been taken into account by the Observatory for Environmental Research (ORE/HYBAM), which initiated research on this topic in 2001 in Ecuador. Indeed it seems to be the only way to get longer datasets, following Marengo's works (2004) about rainfall in the Brazilian Amazonian basin, that will allow for the analysis of rainfall, discharge, and sediment fluxes in the Ecuadorian Amazon, over different time scales, including multiple decades.

Acknowledgments. We thank the participants of the HYBAM/Ecuador project and its partnership institutions in Ecuador, INAMHI and IRD. We also thank the French National Center for Scientific Research (CNRS) and the National Program for Climate Study (PNEDC) for funding this research. We are grateful to the anonymous reviewers, whose comments and suggestions considerably helped improve this manuscript.

\section{REFERENCES}

Armijos, E., 2002: Estudio hidrofísico de las cuencas de los ríos Napo, Pastaza y Santiago dentro del proyecto Hybam. Thesis of engineering, Universidad Central de Ecuador, $126 \mathrm{pp}$.

Bendix, J., and W. Lauer, 1992: Die Niederschlagsjahreszeiten in ecuador und ihre klimadynamische interpretation. Erdkunde, 46, 118-134.

_ R. Rollenbeck, and W. E. Palacios, 2004: Cloud detection in the Tropics-A suitable tool for climate-ecological studies in the high mountains of Ecuador. Int. J. Remote Sens., 25, 4521-4540.

— - _ , and C. Reudenbach, 2006: Diurnal patterns of rainfall in a tropical Andean valley of southern Ecuador as seen by a vertically pointing K-Band doppler radar. Int. J. Climatol., 26, 829-846.

Bès de Berc, S., J. C. Soula, P. Baby, M. Souris, F. Christophoul, and J. Rosero, 2005: Geomorphic evidence of active deformation and uplift in a modern continental wedge-top foredeep transition: Example of the eastern Ecuadorian Andes. Tectonophysics, 399, 351-380.

Buytaert, W., J. Deckers, G. Dercon, B. De Bièvre, J. Poesen, and G. Govers, 2002: The influence of land use changes on the hydrological properties of volcanic ash soils in South Ecuador. Soil Use Manage., 18, 94-100.

, B. De Bièvre, G. Wyseure, and J. Deckers, 2004: The use of the linear reservoir concept to quantify the impact of changes in land use on the hydrology of catchments in the Ecuadorian Andes. Hydrol. Earth System Sci., 8, 108-114.

Cedeño, J., T. De La Cuadra, K. Abata, M. Merizalde, and M. P. Cornejo-Grunauer, 2006: Diagnosticos de probabilidades de lluvias asociados a eventos del ciclo ENOS en la costa del Ecuador. Climate Variability and Changes-Hydrological Impact, IAHS Publication 308, Wallingford, United Kingdom, 369-374.

Cuartas, L. A., and G. Poveda, 2002: Balance atmosférico de humedad y estimación de la precipitación reciclada en Colombia según el Reanalisis NCEP/NCAR. Meteor. Colombiana, $\mathbf{5}, 49-57$.

Erazo, A., and R. Hoorelbecke, 1999: Balance hídrico superficial de la cuenca del Río Pastaza. HIBAM Publication, Quito, Ecuador, 46 pp.

Espinoza, J. C., P. Frayzy, J. L. Guyot, J. J. Ordoñez, R. Pombosa, and J. Ronchail, 2006: La variabilité des débits du rio Amazonas au Pérou. Climate Variability and ChangesHydrological Impacts, IAHS Publication 308, Wallingford, United Kingdom, 424-429.

Favier, V., P. Wagnon, and P. Ribstein, 2004: Glaciers of the outer and inner tropics: A different behaviour but a common response to climatic forcing. Geophys. Res. Lett., 31, L16403, doi:10.1029/2004GL020654.

Figueroa, S. N., and C. Nobre, 1990: Precipitation distribution over central and western tropical South America. Climanalise, 5, 36-47.

Francou, B., M. Vuille, V. Favier, and B. Cáceres, 2004: New evidence for an ENSO impact on low latitude glaciers: Antizana 15, Andes of Ecuador, $0^{\circ} 28^{\prime}$ S. J. Geophys. Res., 109, D18106, doi:10.1029/2003JD004484.

Guyot, J. L., 1993: Hydrogéochimie des Fleuves de l'Amazonie Bolivienne. ORSTOM ed., IRD Institut, $261 \mathrm{pp}$.

, N. Filizola, J. Quintanilla, and J. Cortez, 1996: Dissolved solids and suspended sediment yields in the Rio Madeira basin, from the Bolivian Andes to the Amazon. Erosion and 
Sediment Yield: Global and Regional Perspectives, IAHS Publication 236, Wallingford, United Kingdom, 55-63.

Hastenrath, S., 1981: The Glaciation of the Ecuadorian Andes. A.A. Balkema Publishers, 159 pp.

Hoorelbecke, R., and V. Perez, 1999: Datos meteorológicos de la cuenca del Río Napo. HIBAM Publication, Quito, Ecuador, $213 \mathrm{pp}$.

_, R. Pombosa, and J. Roura, 1999: Balance hídrico superficial de la cuenca del Río Santiago. HIBAM Publication, Quito, Ecuador, $35 \mathrm{pp}$.

Horel, J. D., A. N. Hahmann, and J. E. Geisler, 1989: An investigation of the annual cycle of convective activity over the tropical Americas. J. Climate, 2, 1388-1403.

Johnson, A. M., 1976: The Climate of Peru, Bolivia, and Ecuador. World Survey of Climatology: Climates of Central and South America, W. Schwerdtfeger, Ed., Elsevier, 147-219.

Kalnay, E., and Coauthors, 1996: The NCEP/NCAR 40-Year Reanalysis Project. Bull. Amer. Meteor. Soc., 77, 437-471.

Kousky, V. E., M. T. Kayano, and I. F. A. Cavalcanti, 1988: A review of the southern oscillation: Oceanic, atmospheric circulation changes and related anomalies. Tellus, 36A, 490-504.

Laraque, A., C. Céron, E. Armijos, R. Pombosa, P. Magat, and J. L. Guyot, 2004a: Sediment yields and erosion rates in the Napo River Basin: An Ecuadorian Andean Amazon tributary. Sediment Transfer through the Fluvial System, IAHS Publication 288, Wallingford, United Kingdom, 220-225.

_ J. L. Guyot, and R. Pombosa, 2004b: Hidroclimatología de la cuenca amazónica del Ecuador y su hidrosedimentología (Ejemplo de la cuenca del Napo). Geología de la Cuenca Oriente, P. Baby, M. Rivadeneira, and R. Barragan, Eds., IRD, IFEA, PETROECUADOR, 131-151.

Marengo, J. A., 2004: Interdecadal variability and trends of rainfall across the Amazon Basin. Theor. Appl. Meteor., 78, 7996.

Molinier, M., J. L. Guyot, E. Oliveira, and V. Guimarães, 1996: Les régimes hydrologiques de l'Amazone et de ses affluents. L'hydrologie tropicale: Géoscience et outil pour le développement. IAHS Publication 238, Wallingford, United Kingdom, 209-222.

Moreno, F., and A. Tapia, 2001: Regionalización hidrometeorológica de las cuencas amazónicas. Thesis of engineering, Universidad Central de Ecuador, 75 pp.

Muller, F., F. Seyler, and J. L. Guyot, 1999: Utilisation d'imagerie radar (ROS) JERS-1 pour l'obtention de réseaux de drainage. Exemple du Rio Negro (Amazonie). Hydrological and Geochemical Processes in Large Scale River Basins, HIBAM Publication, Manaus, Brazil, 15-19.

Nobre, C. A., 1983: Amazonia and climate. Proc. WMO Technical Conf. on Climate for Latin America and the Caribbean, Colombia, WMO, 409-416.

Perez, V. P., 2000: Balance hídrico superficial de la cuenca del Río Napo. Ph.D. thesis, Universidad Central del Ecuador, 132 pp.
Pourrut, P., 1994: Climat de l'equateur. L'Eau en Equateur, Principaux Acquis en Hydroclimatologie. ORSTOM ed., $146 \mathrm{pp}$.

Poveda, G., 2004: La hidroclimatología de Colombia: Una síntesis desde la escala inter-decadal hasta la escala diurna. Rev. Acad. Ciencias, 28, 201-222.

Pulwarty, R. S., R. G. Barry, and H. Riehl, 1992: Annual and seasonal patterns of rainfall variability over Venezuela. Erdkunde, 46, 273-289.

$\longrightarrow,-$ C. M. Hurst, K. Sellinger, and L. E. Mogollon, 1998: Precipitation in the Venezuelan Andes in the context of regional climate. Meteor. Atmos. Phys., 67, 217-237.

Rao, V. B., I. F. A. Cavalcanti, and K. Hada, 1996: Annual variation of rainfall over Brazil and water vapor characteristics over South America. J. Geophys. Res., 101, 26 539-26 551.

RDI, 1996: Acoustic Doppler Current Profilers-Principles of Operation: A Practical Primer. 2d ed. RDI, 54 pp.

Ronchail, J., and R. Gallaire, 2006: ENSO and rainfall along the Zongo valley (Bolivia), from the Altiplano to the Amazon basin. Int. J. Climatol., 26, 1223-1236.

—, G. Cochonneau, M. Molinier, J. L. Guyot, A. Goretti de Miranda Chaves, W. Guimarães, and E. de Oliveira, 2002: Rainfall variability in the Amazon Basin and SSTs in the tropical Pacific and Atlantic oceans. Int. J. Climatol., 22, 1663-1686.

Rossel, F., 1997: Influence du Niño sur les régimes pluviométriques de l'equateur. Ph.D. thesis, Montpellier University, $289 \mathrm{pp}$.

Trenberth, K. E., and J. W. Hurrell, 1994: Decadal atmosphereocean variations in the Pacific. Climate Dyn., 9, 303-319.

UNESCO, 1980: Vegetation map for South America. Scale: 1/5 000000.

Vuille, M., R. S. Bradley, and F. Keimig, 2000a: Interannual climate variability in the Central Andes and its relation to tropical Pacific and Atlantic forcing. J. Geophys. Res., 105, 12 44712460 .

,-- , and $-2000 \mathrm{~b}$ : Climate variability in the Andes of Ecuador and its relation to tropical Pacific and Atlantic sea surface temperatures anomalies. J. Climate, 13, 2520-2535.

Ward, J. H., 1963: Hierarchical clustering to optimize an objective function. J. Amer. Stat. Assoc., 58, 236-245.

Williams, E., A. Dall'Antonia, V. Dall'Antonia, M. de Almeida, F. Suarez, B. Liebmann, and A. C. Mendes Malhado, 2005: The drought of the century in the Amazon Basin: An analysis of the regional variation of rainfall in South America in 1926. Acta Amazonica, 35, 231-238.

Williams, M. W., E. W. Hood, G. Ostberg, B. Francou, and R. Galarraga, 2001: Synoptic survey of surface water isotopes and nutrient concentrations, páramo high elevation region, Antisana ecological reserve, Ecuador, Arctic. Arctic Antarctic Alpine Res., 33, 397-403. 